Rodolfo Daniel Silva-Martínez, Alessandro Sanches-Pereira, Willington Ortiz, Maria Fernanda Gómez Galindo, Suani Teixeira Coelho

\title{
The state-of-the-art of organic waste to energy in Latin America and the Caribbean
}

Challenges and opportunities

Originally published in:

Renewable Energy,

156 (2020), pp. 509-525

DOI: 10.1016/j.renene.2020.04.056 
Rodolfo Daniel Silva-Martínez $a$, * Alessandro Sanches-Pereira $a, b, c$ Willington Ortiz d

\section{The state-of-the-art of organic waste to energy in Latin America and the Caribbean}

\section{Challenges and opportunities}

a Institute of Environmental System Research, University of University of São Paulo, Institute of Energy and Environment, São Paulo, Brazil

b Instituto 17, São Paulo, Brazil

c KTH Royal Institute of Technology, Stockholm, Sweden

d Wuppertal Institute for Climate, Environment and Energy, Wuppertal, Germany

e Energy, Materials, and Environment Laboratory, Department of Chemical Engineering, Universidad de La Sabana, Chía, Colombia

* Corresponding author:

Rodolfo Daniel Silva-Martínez

University of São Paulo

Institute of Energy and Environment

Research Group on Bioenergy

Av. Prof. Luciano Gualberto, 1289

Vila Universitaria, São Paulo, SP, 05508-900

Brazil

E-mail: rodolfo.silva.m@usp.br

This is the author's version of a work that was accepted for publication. Changes resulting from the publishing process, such as editing, corrections and structural formatting, may not be reflected in this document. Changes may have been made to this work since it was submitted for publication. A definitive version was subsequently published in the Journal cited above. 
THE STATE-OF-THE-ART OF ORGANIC WASTE TO ENERGY IN LATIN AMERICA AND THE CARIBBEAN: CHALLENGES AND OPPORTUNITIES

\author{
Rodolfo Daniel Silva-Martinez ${ }^{\mathrm{a}, *}$, Alessandro Sanches-Pereira ${ }^{\mathrm{a}, \mathrm{b}, \mathrm{c}}$, Willington Ortiz ${ }^{\mathrm{d}}$, Maria \\ F Goméz e, Suani Teixeira Coelho a \\ a University of São Paulo, Institute of Energy and Environment, Research Group on Bioenergy - Av. Prof. Luciano Gualberto, 1289 - Vila \\ Universitaria, São Paulo - SP, 05508-900, Brasil \\ bInstituto 17, São Paulo, Brazil - R. Prof. Pedro da Cunha, 65 - Perdizes, São Paulo, Brazil \\ c KTH Royal Institute of Technology, Department of Energy Technology - Brinellvägen 68 \\ S-100 44 Stockholm Stockholm, Sweden \\ d Wuppertal Institut - Döppersberg 19, 42103 Wuppertal, Germany
}

e Energy, Materials, and Environment Laboratory, Department of Chemical Engineering, Universidad de La Sabana, Campus del Puente del Común Km. 7 Autopista Norte. Chía, Colombia

*Corresponding author

E-mail addresses: rodolfo.silva.m@usp.br (Rodolfo Daniel Silva-Martinez),perei@usp.br (Alessandro Sanches-Pereira),

willington.ortiz@wupperinst.org (Willington Ortiz), maria.gomez@unisabana.edu.co (Maria F Goméz), Suani27@hotmail.com (Suani Teixeira Coelho)

ABSTRACT: Organic waste to energy (OWtE) technologies have been developed and implemented in Latin America and the Caribbean (LAC) countries. However, they are still far away to significantly contribute not only to treat the ever-increasing waste volumes in the region but also to supply the regional energy demand and meet their national carbon emission goals. The technical complexity of these technologies aligned with lack of research, high investment costs and political deficiencies have not allowed for an appropriate implementation of OWtE in the region, where the applicability of large-scale plants remains to be demonstrated. This research presents the state-of-the art of OWtE technologies in the context of the LAC countries based on archival research method; as well as the challenges and opportunities that the region is facing for an adequate implementation of these technologies. The main findings show that OWtE have the potential to improve waste and energy systems in the region by reducing environmental impacts along with a series of social and economic benefits, such as increasing access to a sustainable energy supply. Diverse researches indicate principally anaerobic digestion, fermentation (bioethanol, biodiesel, etc.), microbial fuel cells, gasification and pyrolysis as efficient technologies to treat solid organic wastes and produce bioenergy.

Keywords: Organic waste; bioenergy; waste to energy; Latin America; Caribbean 


\section{INTRODUCTION}

Throughout the world, several studies and actions have been successfully carried out to apply Organic Waste-to-Energy (OWtE) technologies for managing and treating solid organic residues. In the specific case of the Latin America and the Caribbean (LAC) countries, these practices have already been developed and implemented. However, there is still a long way to significantly contribute, not only to manage and treat the ever-increasing waste volumes in the region, but also to supply the regional energy demand and meet their national goals for carbon emissions. Hence, biowaste (i.e. household organic wastes and forest and agricultural residues) is still not sufficiently recognized as valuable energy source with significant potential, and is largely underused in the region.

OWtE technologies in the LAC countries differ from one country to another. For the last 40 years, local experiences have varied regarding implementation strategies and sectorial applications due to political contexts and technological changes in the period. High upfront costs, deficiency in access to sophisticated technology, lack of participation of stakeholders, and public policy deficiencies have not allowed for an appropriate implementation of relevant technologies for biowaste treatment in the region resulting sometimes in serious environmental and health impacts during their disposal [1].

In addition, the continuing increase of electricity demand and environmental impacts due to the high proliferation of wastes in the region have made local stakeholders (e.g. farmers, waste managers, researchers, etc.) look for ways to optimize existing waste treatment options, which could allow energy recovery [2]. Thus, the idea of searching for and implementing affordable waste to energy (WtE) strategies has been lately gaining momentum and fostering debate on whether specialized technologies, such as thermochemical or biochemical, can assist on supplying local energy demands. Other important benefits, such as improving nutrient recycling and avoiding the consumption of conventional fossil fuels, are encouraging the adoption of these technologies. Local projections expect biomass (e.g. biofuels) and biowaste to significantly contribute for energy production, but the applicability of such projects for large-scale production remains to be demonstrated in most of the cases in the region [3]. 
Although the preliminary examination of the body of knowledge shows that diverse literature exists related to OWtE in LAC, such as publications from the Network for Biodigesters in Latin America and the Caribbean (RedBioLac), academic papers from distinguished international journals, etc., a state-of-the-art literature review and a broad frame of literature reference have not been adequately developed. Hence, the overarching goal of this research article is to contribute to the development, adoption and diffusion of technologies that generate social, economic and environmental values from the use/treatment of organic residues in the LAC region, by building a state-of-the-art of the regional and current technological context. In order to advance towards this goal the present study has a twofold aim: On the one hand, it aims to systematize the current state of knowledge about the technological and environmental situation of OWtE in the LAC context. On the other hand, it targets to identify knowledge gaps, challenges, and opportunities for further development and promotion of these technologies as tools for achieving the sustainability targets in the region, such as reducing carbon emissions under the Paris Agreement. It is important to mention that this indepth and descriptive literature review attempt to cover all aspects and facets of the matter from a regional context.

\section{LITERATURE REVIEW STRATEGY}

The research methodology used is the Archival Research Method (ARM), which was implemented as a method to conduct and evaluate the existing literature and domain files. The ARM is regarded as a research strategy for the examination of previously recorded facts, which depend on the originality of the documents, primary and secondary official files and records gathered by other investigators and researchers [4].

In order to accomplish an exhaustive literature review was necessary to cover an in-depth and wide range of publications. The ARM and analysis comprises the following steps:

i. Defining database source: the review covered well-established scientific databases (i.e. Scopus, ScienceDirect, Web of Science, etc.) and publications from renowned international institutions (i.e. United Nations Economic Commission for Latin America and the Caribbean (ECLAC), United Nations Environment Program (UNEP), World Energy Council (WEC), etc.). The data collection was conducted in three languages: English, Portuguese, and Spanish. 
ii. Delimitation of the scope: the timeframe covered almost two decades, from 2000 until 2018, in order to include recent and historical publications.

iii. Defining unit of analysis: the review included single research papers, reports, books, and Internet articles. Given the large number of academic articles, the selected research articles are from the top $25 \%$ international scientific journals, according to the SCImago Journal Rank (SJR) indicator, based on the research topic related to waste, environment, and energy themes. The SJR rank is an indicator to measure scientific influence of academic journal and it accounts for both the number of citations received by a journal and the importance or prestige of the journals where such citations come from. Other sources were Institutional websites, academic databases containing reports, MSc theses and PhD dissertations, among other sources of scientific publications.

iv. Sampling: the first sample of documents was defined by searching the selected keywords and Boolean connectors: lignocellulos* OR organic OR biowaste AND

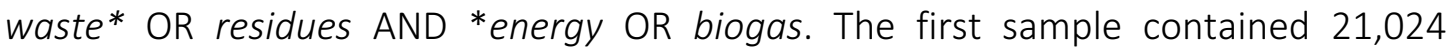
publications.

v. Applying regional filtering: collected documents were filtered according to the region of interest and considered all countries and sub-regions in LAC: North, Central and South America and Caribbean Islands. This step reduced the number of publications from 21,024 to a second sample with 482 documents.

vi. Conducting a general compilation: the documents from the second sample were then stored and organized to discard repeated information and avoid duplicity. As a result, the second sample was reduced to 342 publications.

vii. Defining final sample: the third sample was classified by geographical scope and through deductive analysis was categorized in two main topics: thermochemical and biochemical technologies, following by a sub-categorization on the specific type of technology (i.e. combustion, gasification, pyrolysis, anaerobic digestion, fermentation, landfilling, and microbial fuel cells). After reading all abstracts and conclusions of each one of the documents within the third sample, documents containing very technical information (i.e. documents fully describing biochemical process) and/or specific research articles (i.e. documents describing budget details) were discarded. The fourth and final sample contains 196 documents and it was organized by country of 
interest. Figure 1 illustrates the sampling steps and the number of selected publications for each one of the steps.

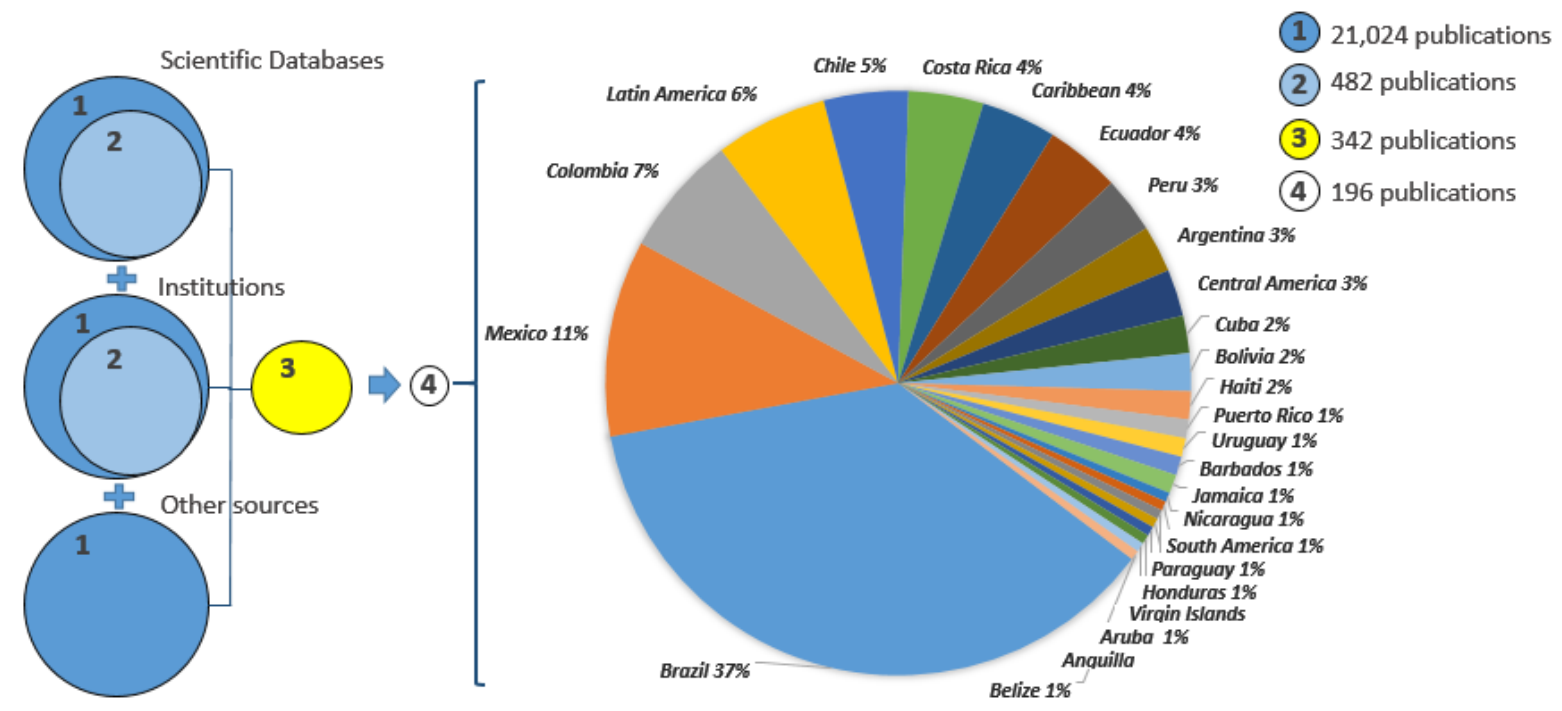

Figure 1: Sampling steps and number of documents for each one of the steps

Once the relevant documents were selected, a deep and detailed content analysis was carried out. Content analysis (CA) is a research technique used to make replicable and valid interpretations by systematically evaluating texts (e.g. academic articles, reports, and other publications) and converting them into valuable information that allows researchers to examine nuances of organizational behaviors, stakeholder perceptions, and societal trends [5]. The aim of using CA in this case was to collect information that was useful for understanding the current state, viability and the potentials of the thermochemical and biochemical technologies in the given geographical context; as well as observations about research gaps, opportunities and challenges. To achieve this, each document was read and analyzed, and coded, highlighting and selecting relevant pieces of information. The goal was to search for patterns and cluster observations into related subtopics to finally compare and synthesize their state in each subregions and country. After gathering relevant information from selected publications, they were organized into a summary table (see Table 2). 


\section{THE CURRENT TECHNOLOGICAL CONTEXT IN LATIN AMERICA AND THE CARIBBEAN}

Every year millions of tons of agricultural, forest, and urban waste are generated in LAC. Their potential as alternative energy sources has been identified. In fact, several studies in recent years have presented technical, environmental, and economic analyses of different OWtE technologies as well as their comparative performances for bioenergy production. However, they are not fully explored in the region.

In order to facilitate the analysis and presentation of results, this review follows the technological classification established by the WEC [6] to present the compiled information in two main technological classifications and their subcategories: a) thermochemical and b) biochemical processes.

Thermochemical technologies include combustion or incineration, gasification and pyrolysis. Among them, incineration is the most commonly practiced in the region [7], [8] with an estimated large theoretical potential for expansion. Nevertheless, nowadays there is an ongoing debate on whether this is the right organic waste treatment method, considering the negative environmental effects and the low process efficiency these technologies portray when compared to other treatments such as pyrolysis and gasification systems.

Biochemical technologies comprehend anaerobic digestion, fermentation, landfilling gas capture, and microbial fuel cell (MFC) technologies [6]. Research and Development (R\&D) in the region has been mostly focused in small-scale anaerobic digesters (AD) [9] and landfilling. In addition, R\&D has studied fermentation to a lesser extent. Nonetheless, interest in largescale biodigesters, second-generation (2G) biofuels, and MFCs has been gaining ground in countries such as Argentina, Brazil, Chile, Colombia, and Mexico.

\subsection{Thermochemical technologies}

Existing thermochemical technologies (e.g. incineration, gasification, and pyrolysis) use heat to promote chemical transformations of biomass into energy and chemical products. On the one hand, these technologies follow similar processes to create three main products: solid (e.g. char and/or ash), liquid (e.g. bio-oil or tar), and gas (e.g. syngas or producer gas). On the other hand, each process uses different reaction conditions such as temperature, pressure, 
heating rate, residence time, reactive or inert atmosphere, purge gas flow rate, and so forth [6].

Currently, incineration is the most used technology in the region, but gasification and pyrolysis present some advantages over it such as being a more thermally efficient and flexible system regarding the utilization of downstream products (e.g. biofuels, chemical or fertilizers) [10]. The decision for selecting any of these technologies is related to:

- The type of residues or lignocellulosic materials being treated;

- What energy carries are being developed; and

- The local interest.

For example, direct combustion can produce steam to later on generate electricity. Gasification produces a lower heating value gas, which can be used to power energy turbines [8]. Furthermore, Parascanu et al. (2017) concluded that for pyrolysis processes, the desirable characteristics of biomass are high volatile matter with a low ash content, and for combustion processes, the biomass has to show high low heating value (LHV) with also a low ash content. In the case of gasification processes, the biomass ought to have high fixed carbon $^{1}[11]$. The implementation of thermochemical technologies might be crucial in the upcoming years because they present a promising pathway for taking advantage of urban residues in various countries of the region. Especially, the development of small-scale commercial systems (e.g. gasification) for the production of power in rural areas [8].

\subsubsection{Combustion or incineration}

Combustion technologies, also referred as incineration, have been implemented in the LAC region as an alternative for waste or residue treatment. In the Caribbean Islands, biomass from agricultural and forest residues is utilized to produce electricity through combustion techniques. In countries like Dominican Republic [12] or Cuba, combustion is practiced to employ the energy content of residues such as sugarcane straw and bagasse, rice husk, coffee husk, and firewood [13]. In the British Virgin Islands most wastes are incinerated, despite the high costs involved [7]. Conversely, in Puerto Rico for example, there is no incineration of waste or residues, where all waste are landfilled or recycled [7].

\footnotetext{
${ }^{1}$ Fixed carbon is the final calculation of the amount present in a biomass sample after the percentages of moisture, ash, and volatile matter have been determined.
} 
In the case of Central America, currently sugarcane bagasse and straw are the only agricultural residues to produce energy at large scale [8]. Almost half of the existent sugar mills in the subregion produce heat and power through combustion processes (e.g. combined heat and power (CHP) plants), supplying a reasonable amount of electricity in the region [8]. In Guatemala and Honduras, these treatment processes play a major role for electricity supply [14]. Around $67 \%$ of sugar mills in Guatemala and $100 \%$ in Honduras are already operating under CHP schemes firing bagasse [8]. Regarding scale, one of the largest sugar mills in the region is located in Nicaragua; The San Antonio sugar mill (NSEL), is the top electricity producer from sugarcane bagasse in the region, currently with an installed capacity of around $79 \mathrm{MW}$ [15]. In Mexico, there are around 59 projects for self-power supply through combustion processes using waste biomass (i.e. mostly sugarcane bagasse) with an installed capacity of $500 \mathrm{MW}[16]$.

In the case of South America, particularly in Brazil, bagasse from sugarcane is the main source of agro electricity with an operating power potential of more than 9 GW [17], considering that burning bagasse is still by far the least cost option in comparison with other thermochemical routes [18]. Additionally, being Brazil one of the largest agricultural producers globally with large generation of agricultural residues [19], it has also already a considerable number of biomass combustion power plants running on different feedstock beyond sugarcane bagasse. For example, black liquor (1.7 GW), wood residues (371 MW), rice husk (36 MW), charcoal (35 MW), elephant grass (32 MW) and palm oil (4 MW) [17]. In addition, the first thermoelectric plant for eucalyptus residues was already authorized, with a capacity of $50 \mathrm{MW}$ in the State of Mato Grosso do Sul and should start operation by 2021. The owner of the thermoelectric plant, is also planning to install two more plants in the near future [20].

Other countries in LAC have identified their potential for application of local agroindustrial and forest residues as alternative energy sources in direct combustion processes. In Costa Rica, for example, the agricultural sector produces approximately 1.5 million tons of residues per year mainly from banana, coffee, sugarcane pineapple and palmoil. However, these residues are currently also in demand as supplement for fodder. Therefore a potential exists in using some percentage of these residues to generate heat by direct combustion of the raw residues [21], without affecting the fodder demand. 
Incineration can be also used as an energy recovery alternative to reduce the impacts of household solid waste (HSW), which are usually landfilled in LAC without any pretreatment (e.g. sorting, recycling, and so forth). Various studies [22][23][24] have demonstrated its energy potential and technical and economic feasibility of incineration process as an efficient way to treat HSW. Furthermore, a study by Nordi et al. (2017) demonstrated that removing the organic fraction of the HSW increase efficiency of energy production [24]. Therefore, they suggest that incineration should not be a solution for treating the organic fraction of municipal solid waste (OFMSW). It is important to mention that the costs (e.g. upfront and operation costs) of incineration plants for HSW as an appropriate solid waste management technology in Brazil, for example[23], as in most of the countries of the region, are still far too high. For example, incineration in Suriname is not feasible due to its high costs and high humidity contents in the wastes [25].

\subsubsection{Densification}

To promote better and faster combustion processes, diverse densification techniques exists and have been applied in the region such as pelletizing, briquetting and torrefaction, which are useful for achieving adequate properties and a higher calorific value of original materials. These pretreatment technologies also provide advantages such as increase of bulk density, reduction of transportation, and storage costs, which in turn facilitate material handling [26]. For example, pelletizing wood residues can have economical attractive opportunity for areas with conifer plantations because densification can increase the heating value to $22.13 \mathrm{MJ} / \mathrm{kg}$ and meet the requirements for high-quality pellets [27].

Even though the pellet industry is developing in LAC, there is still large potential to pelletize agricultural and wood residues. Nowadays, Argentina [19][28], Brazil [19][26][29], Chile[19][30], Costa Rica[21] [31], Honduras [19], Mexico [19], and Uruguay [28] produce pellets at industrial level for national markets but their exports are still insignificant [19]. Other countries show tangible potential to produce pellets [28] such as Colombia [19] [32] and Peru [33].

In the region, even though, specific policies have not yet been established for the regulation of pellets production, it is expected that the topic will advance in the years to come. Pelleting has been lately calling the attention of scientists and decision makers in the region, as an effective way of densifying the energy contained in lignocellulosic wastes and wood, and to 
significantly replace the direct burn of agricultural wastes that produce large amounts of gaseous pollutants harming the environment and health of people [19].

The current small number of pelletizing industries and underutilization of wood residues in the region can be attributed to undeveloped national markets for wood pellets, lack of knowledge on technical and economic advantages of pellet production, competition with cheap natural gas, and costly transportation that creates a challenging environment for residual biomass logistics [19].

Studies from Gaitán-Álvarez \& Moya (2016) [31] and Sánchez et al. (2017) [34] show that local potential for producing pellets from torrefied biomass (e.g. wood residues, avocado seeds, and husks) presents adequate properties and high calorific value. In the Dominican Republic there has been governmental support for the production of briquettes for their use in small and medium size industries [12]. Furthermore, in Colombia, researchers such as Marrugo et al. state that using biomass residues in the form of pellets, provides an opportunity to successfully incorporate a high quality biofuel to the national agroindustry chain [35].

\subsubsection{Gasification}

Gasification is the thermochemical conversion of an organic material (e.g. biomass) into a valuable gaseous product, called syngas, and a solid product, called char [36]. Different types of gasifier configurations have been developed: Downdraft (DG) gasifiers, which are the most often offered commercially, followed by fluidized beds (FB), updraft and other gasifier types [37].

In the Caribbean islands, the review by Mohee (2015) [7] on the current status of solid waste management in small island developing states, points out the following facts: In Aruba, the company WastAway patented a new technology for the conversion of unsorted HSW into a sub-product, which is consequently gasified for steam and electricity generation [38]. In Barbados, Cahill Energy is planning to implement gasification in order to meet the country's target of replacing $29 \%$ of its oil-based electricity with renewables by 2029 [39]. In the case of Cuba, the first gasification plant was installed in 2010 using biomass as feedstock [40], producing electricity for 96 households, a bakery, a primary school, and for the water supply system. With a power capacity of $6.5 \mathrm{~kW}$, this small scale gasification plant currently saves 
more than 18 tons of diesel fuel [41]. Gasification is an emerging technology in the Caribbean islands due to various benefits associated with it [7]. Furthermore, aside of agricultural and wood residues, gasification offer efficient energy outputs for the treatment of other wastes such as medical, scrap tires, used oil, among others.

In Central America, there are no operating gasification plants and no plans to develop this type of project in the coming years [42]. Furthermore, the successful case in Cuba, is seen in the subregion as a valuable experience for future transfer of technologies for design, start-up and operation of small scale gasification systems [8]. However, barriers such as financial, institutional, technical and human resources should be surpassed to make these technologies technical and economically feasible [41]. According to Cutz et al., (2016) by implementing DGs and FBs gasification systems running with logging residues in Central America, the subregion has a capacity to produce between 96 to $175 \mathrm{MW}$, and up to $31 \mathrm{MW}$ from agroindustrial residues. Meanwhile up to some $150 \mathrm{MW}$ could be produced by combusting these residues [8].

Looking at South America, diverse experimentation indicates that gasification has the ideal characteristics for producing energy. For example in the case of Chile, the potential of FBs gasifiers was found for the electricity production from wheat, but these technologies have not been commercially used, due to the fact that they do not have a competitive price yet [43]. García et al. (2017) [44], in Colombia, also suggests that gasification production costs should be improved in order to be competitive with traditional technologies. This study also proved that gasification is the best technical scenario for hydrogen production along with ethanol and electricity. In Mexico, the study by Rincón et al. (2014) [45] proved gasification as the most advantageous system to generate important contributions of electricity and heat. In other countries such as Guyana, gasification has been proposed as a waste management technology, while in Suriname, gasification of rice husk was investigated as a potential solution to the energy and waste disposal problem [7].

A research group at the Universidad Nacional de Colombia has designed and built a system for biomass gasification involving a fixed-bed parallel flow reactor. The results show good production of quality syngas from biomass such as wood, cocoa waste, coconut and coffee husk [46]. Lastly, the authors point out that it is expected that projects in the future would allow commercial gasification systems in Colombia to produce low-cost energy; for this, also 
further research is necessary. In line with this, García et al. (2017) analyzed the production of hydrogen through gasification of coffee cut-stems and argue that the process has the potential to produce high $\mathrm{H} 2 / \mathrm{CO}$ ratios, but it needs to be benchmarked with other technologies and evaluated in the context of integrated biorefineries [44]. In Ecuador, Narvaez et al. (2013) [47] compared several WtE technologies that can be applied for the management of solid wastes, highlighting gasification as the most promising in terms of potential power generation.

In Brazil, technologies have been developed for converting biomass into syngas through gasification in downdraft gasifier systems. According to Panwar et al. (2012) [48] this is the most appropriate system for industrial applications such as heating and drying of agricultural and industrial products. For example, in the Amazon, the electricity needs of the communities and small towns can be satisfied through gasification systems [49]. Moreover, in other parts of the country this technology already gained ground in the business sector, although no project has been operated long enough to reveal real data useful for assessing performance and costs [50]. Besides, researchers have also been conducting a complementary study in which the gasification potential of rice husk is being evaluated [51]. Market potential for gasification technologies was also detected for the agricultural residues in Brazil [52].

Conclusively, gasification is one of the most promising technologies for its mitigation and generation of energy such as heat, hydrogen, ethanol and electricity. Among the benefits of biomass gasification, aside of waste treatment and energy supply to meet demand, are sustainability, reducing greenhouse gas emissions, regional economic development, social and agricultural development and a regular supply of energy [49].

\subsubsection{Pyrolysis}

Pyrolysis is an effective and efficient thermochemical process in which the chemical constituents of the biomass are thermally degraded and transformed into bio-oil and an inert gas. It is the previous stage of combustion and gasification [53] and comprises the thermal decomposition of material in absence of oxygen. The major benefit of pyrolysis compared to other technologies, is that this bio-oil can be then transformed into fuels for the transport sector (e.g., diesel and gasoline), or as feedstock for the chemical industry [50]. 
In the Caribbean Islands, even when pyrolysis is the least thermochemical technology practiced according to Mohee et al. (2015) [7], there are tentative cases being discussed such as in the implementation of a plant in Haiti, from which biochar could be employed to treat agricultural residues and bio-oil to supply fuel in rural areas [54]. Also, pyrolysis has been proposed in other countries of the region such as Jamaica and Puerto Rico for managing used tires [55], or in Anguilla, where a pyrolysis plant was proposed to reduce the amount of wastes landfilled by $90 \%$ and supply $30 \%$ of the Island's energy [56]. Also in Saint Kitts a plant with a capacity of 5MW was proposed as a renewable energy alternative [57].

With respect to Central America, no discussion has been developed, as pyrolysis is reasoned to be the least preferable technology in the region [8]. In addition, according to Cutz et al. (2016) [8] there are currently no plans to build any pyrolysis plants in the region. However, in the case of Mexico, a study by Gracida-Alvarez et al. (2016) [58] support the implementation of these technologies to produce renewable fuels in the country. The study results show that this technology has the potential to displace up to $7 \%$ of the current annual fossil transportation fuel consumption.

In South America, pyrolysis is employed for the production of charcoal from wood in Guyana, [59]. Slow pyrolysis techniques have been used since ancient times in the Brazilian Amazonia to produce biochar, which is an energy-dense solid product [60]. Nowadays, other cases have occurred in Brazil. For example, "Bioware Tecnologia" which is supported by the University of Campinas (Unicamp) [61]. Other studies have demonstrated the great potential and efficiency of pyrolysis treatments in countries like Brazil [62] [63] [64] [65], Colombia [32] [53] [66], and Ecuador [67]. However, these studies point out that further research is necessary to understand more on the economics and logistics of the process.

\subsection{Biochemical}

Biochemical organic waste treatment technologies are based on the decomposition of organic matter under microbial action to produce biogas and compost. The conversion technologies utilize microbial processes to transform waste such as food, forest and agricultural wastes [6]. In recent years, these technologies have been developed and implemented in the region in various extents. Interest in large-scale biodigesters, second generation (2G) biofuels and MFC's have been gaining ground, hereafter described. 


\subsubsection{Anaerobic Digestion}

The R\&D of anaerobic digestion (AD) of organic residues in LAC has mainly covered smallscale digesters, which are typically used to produce biogas for heating and cooking purposes [9]. The main reasons are the low investment cost and the low maintenance that these technologies require, which in turn has resulted in multiple successful biodigesters designs and adoption of these small-scale technologies [1]. Since 2009, the regional coordination of R\&D programs in LAC is promoted and assisted mostly by the Network for Biodigesters in Latin America and the Caribbean (RedBioLAC), which was established by the nongovernmental organization Green Empowerment, with support from the US Environmental Protection Agency (US EPA) and the Wuppertal Institute for Climate, Energy and Environment (WISIONS).

It is important to mention that interest in large-scale biodigesters has been gaining ground in the last years in some countries (i.e. Argentina, Brazil, Bolivia, Chile, Colombia, Costa Rica, Mexico, Paraguay, Puerto Rico and Uruguay) in LAC. In the last decade, research on treating residues via large-scale $A D$ has been carried out in the region with some interesting results on biomethane potential and techniques e.g. [68][69].

\subsubsection{Small-scale digesters}

The first small-scale biodigesters were installed in LAC in the 1970s. In the following decade, most of the countries in the region had developed experiences with these technologies. This process was accelerated on the 1990s and early 2000s [1] and small-scale ADs have spread successfully in rural zones of Latin America. These low-cost anaerobic digesters are considered an appropriate technology that helps expanding modern energy services in developing countries, especially increasing households' access to energy [70]. Additionally, the implementation of these digesters has proven to be an efficient way to improve sanitation and decrease illnesses [71].

The main types of small-scale biodigesters installed in the region are the fixed dome digester and the tubular Taiwanese model. However, the low-cost and non-mechanized AD designs of the Taiwanese-model digester replaced the fixed dome on the late 1990s. Hence, Latin American countries have been successfully treating agricultural manure since the first plastic tubular digester was introduced in Colombia in the late 70s. The technology has spread in rural areas of the region, especially in Colombia, Costa Rica, Cuba, Ecuador, Honduras, 
Mexico, Nicaragua [8][72]. Lately, this technology was adapted to harsh climate conditions of some Andean countries such as Bolivia [73], Peru [74], Chile [75], Ecuador, and Argentina [1]. In Brazil, small scale digesters, known as "Sertanejo" biodigester, were based on the Indian model and implemented in the northeast region of the country [76]. Unfortunately, due to operational problems many farmers had abandoned this technology [77]. There are however a considerable number of small and medium size biodigesters, mainly in the south and southeast regions of the country [78].

The Caribbean Islands present potential for implementation of small-scale AD technologies because the organic fraction of MSW in the region averages around 44\% [7]. Small-scale AD was introduced first in the English-speaking Caribbean countries by the German organization Deutsch Gesellschaft für Technische Zusammenarbeit (GIZ) [79]. In Jamaica, around 200 biogas plants were installed between 1988 and 1993. In the case of Cuba, small-scale AD was introduced as early as 1940, and today there are hundreds of digesters installed in the country [7]. In Belize, a polyethylene digester for converting animal manure into biogas was installed in 2009 [80]. In Haiti, where lack of a basic sanitation services and inadequate waste treatment largely contributed to the ongoing cholera epidemic [81], small-scale AD is a wellestablished technology for biogas production and is used for treating agricultural wastes, domestic wastewaters, and animal manures [82]. In Puerto Rico, benefits from using manure and residues from local dairy farms have motivated interest in using small-scale $A D$ technologies for treating these residues [83].

In the case of Central America, biogas is commonly produced from animal manure and these small-scale biogas plants can produce biogas between 12 and 100 cubic meters $\left(\mathrm{m}^{3}\right)$. Their upfront cost vary from US\$675.00 to US\$ 4,000.00 per plant, which means a production cost ranging from US\$ 40.00 to US\$ 57.00 per cubic meter of biogas [8]. Hence, economy of scale plays an import role even in small-scale technologies when it comes to production cost. The larger a plant is, the lower its production costs are. Besides the numerous Taiwanese-model digesters installed in Central America, research has been developed in various areas of biogas production such as co-digestion experiments [84][85][86][87][88], especially in Costa Rica. In Mexico, the International Institute of Renewable Source (IRRI-México) initiated in 2012 a biogas program in the country, which installed 265 biodigesters in the state of Yucatán, beneficiating more than 2,000 people [1]. 
In South America, low-cost tubular digesters have been also adapted to Andean countries during the last years [70]. They were adapted to work at 3,000-4,000 meters above sea level, where extreme weather conditions and temperature fluctuations prevail [89], [90]. International organizations such as the Netherlands Development Organization (SNV) and the Dutch International Humanist Institute for Cooperation with Developing Countries (Hivos) developed national programs with the objectives of developing national markets for biodigesters to further diffusion/adoption of household digesters in Bolivia and Peru so called "Programa Nacional de Biodigestores" [73]. In addition, there are also some nongovernmental organizations (NGOs) in Peru carrying out integrated projects covering segregated MSW collection and treatment in small waste treatment plant [74]. From 2006 to 2011 more than 30 digesters were implemented in rural Andean communities of the country [89]. Also in Chile, in diverse parts of the country there are biodigesters applied for households to treat wastes of domestic animals [75].

\subsubsection{Large-scale digesters}

Unlike small-scale digesters, large-scale anaerobic digesters have not been widely implemented in the region mainly due to their high investment costs, technical complexity, high maintenance, among other reasons [1]. However, countries like Argentina, Chile, and Brazil have implemented various large-scale ADs based on Continuous Stirred Tank Reactors (CSTR), Up-flow Anaerobic Sludge Blanket (UASB), and cover lagoons.

According to Cutz et al. (2016) [8] in Central America, the theoretical biogas potential of feedstock-based biomass in the region is $1,817 \mathrm{Mm}^{3} /$ year [8]. If this theoretical potential is used in CHP applications, the region could produce $373 \mathrm{MW}$ of electricity and $746 \mathrm{MW}$ of heat [8]. On the one hand, even when decision makers acknowledge the theoretical biogas potential, production has not been yet adequately exploited in the subregion. However, advances in research have been achieved. For example, in Nicaragua the potential of implementing full-scale digesters was found economically viable when combining anaerobic digestion with ethanol fermentation for coffee wastes. Using fermentation byproducts (wash and yeast) acquired during ethanol fermentation as feedstock for the anaerobic digester [91]. There is also in Costa Rica, an AD at the University of Costa Rica, which is able to generate biogas from crop residues, animal manure and food wastes [8]. 
In the case of the Caribbean, there is currently a large-scale plant under construction in Puerto Rico for the treatment of wastes mixed with Napier grass feedstock. This plant will have a power capacity of 2MW [92].

In Argentina, biogas technologies have been fairly well implemented for over 20 years [77], with a list of 105 digesters in 16 provinces of various sizes and technology levels. These belong to the public and private sector, production cooperatives and non-governmental organizations [93]. Although just a small portion of them are used to produce energy. Several plants belonging to municipalities present operational and management problems [94].

Today in Chile around 74 large-scale biodigester exist to treat residues from swine industry, dairy products wastes and wastewaters. Some of the outstanding cases are the treatment plant in Santiago "La Farfana" which around $24 \mathrm{Mm3}$ of biogas are produced annually; or "Santa Irene" y "Las Pampas", with a potential power capacity of 800 kW and generate electricity for approximately 2,500 families [75]. Chamy and Vivanco (2007) [95], estimate a power generation potential of approximately $3.5 \%$ of the installed capacity of Chile.

Colombia is one of the greatest producers of vegetable oils in the world (palm oil, soybean, colza and sunflower). Palm oil mills are characterized by the availability of considerable amounts of by-products of high-energy such as empty fruit bunches (EFB), fibers and shells with high content of organics called palm oil mill effluent (POME) [96]. A study by Arrieta et al. (2007) [96], demonstrates huge potential for increasing the power efficiency of palm oil mills; mainly by the use of these by-products in cogeneration plants; by generating biogas from the anaerobic treatment of the liquid effluents of the process and its conversion into electricity with CHP systems.

In Mexico, in the last decade some programs have emerged to provide financial and technical support for the implementation of AD systems throughout the country. Manly through the state agency Sagarpa (Secretariat of Agriculture, Livestock, Rural Development, Fisheries and Food), several Agribusinesses have been supported to install AD projects (mostly anaerobic lagoons) [97]. However, this has been limited to mainly treat animal manure for electricity generation. Rios and Kaltschmitt (2016) [98] suggest that the collection and biogas production from other organic residues should be carried out to produce energy over the next decades. On May 2017, an AD treatment plant was inaugurated in México City for the treatment of the OFMSW. With a production of $170 \mathrm{~m} 3$ of biogas, equivalent to $175 \mathrm{kWh}$, 
and a production of 1 ton of fertilizer daily production [99]. Also, in the city of Culiacan, since late 2016, the first large-scale dry anaerobic digester was installed for the treatment of agricultural waste with a capacity of 4,500 t/a, and a electrical power of $100 \mathrm{~kW}$ [100]. Another recent successful cases are the AD plants built in Milpa Alta (Mexico City), and Zitacuaro, Michoacán which produce biogas, electricity and fertilizers from cactus wastes [101]. Furthermore, other studies for the anaerobic treatment potential of other residues such as Nejayote (the primary by-product of the nixtamalization) [102], banana peel [103] and the vinasses produced during tequila production [104], were carried out obtaining positive results.

In other countries such as Uruguay and Paraguay the potential of full-scale AD plants has been devised. As mentioned in Moreda (2016) [105] forest and agricultural residues in Uruguay are better off treated in a centralized facility that receives the waste from diverse sources, to generate electricity and digestate materials. Currently, there are two undertakings in Uruguay in which energy is generated with the use of biogas [77]. According to Mercosur [77], there is still little development of biogas large projects in these countries, although Uruguay is already provided with an adequate regulatory framework which incentivize their application. Also in Uruguay, extensive solutions like covered lagoon were widely installed in the past. In this context, even when there is still little development of biogas large projects, the future is promissory. The full potential for methane production is between 52 and $84 \mathrm{Mm} 3$ per year, which is equivalent to $1.3-2.1 \%$ of total primary energy of the country [105].

In Ecuador, in the "Social urban metabolism strategies" for cities, implemented in Quito, biogas technologies were found to be the optimal technology for the conversion of OFMSW into electricity [106]. Besides the biogas utilized to produce electricity, the advantages of heat and fertilizer (guinea pig fertilizer) [107], were also recognized as important products [106].

Biogas production in Brazil has been incentivized and growing due to the latest regulatory advances in the country. On average in 2017 around 135MW of electricity from biogas were generated, which is $14 \%$ more than the previous year [108]. This energy according to Montenegro (2018) [108] comes from 35 large-scale plants using urban, agro-industrial and livestock waste and is equivalent to around $1 \%$ of the National biomass capacity [109]. 
Moreover, there are in total 127 units in Brazil that had been generating energy from biogas with an approximate production of $1.6 \mathrm{Mm} 3 /$ day of biogas according to the data of the Biogas National Registry (Cadastro Nacional do Biogás) [77]. Furthermore, it is expected that biogas generation will contribute even more, considering that in 2017 the energy plan included biogas in electric power expansion for the first time, and the recent ratification of "Renovabio", which is the energy ministry's program for the development of the biofuels industry. The Brazilian potential for biogas production, ranges from 200,000 to 312,000 Million $\mathrm{m}^{3} / \mathrm{yr}$ and corresponds to an installed power range of 4.5 to $6.9 \mathrm{GW}$ (about $4.9 \%$ of all current installed capacity in the country) [110]; these results demonstrate that biogas potential in Brazil is high, due to the large generation of organic waste, especially in the agriculture sector. The $\mathrm{CO}_{2}$ avoided emission, may be up to $19.8 \mathrm{MtCO}_{2 \text { eq }} / \mathrm{yr}$, which is approximately $5 \%$ of the National emissions [110]. At the same time, several other studies have been carried out in the country to test the potential of anaerobic digestion from various sources [111][112][113][114]. In addition, several more carried out for the specific case of vinasse from the sugarcane industry have found out that the use of vinasse through $A D$ technologies as a source of energy has great potential energy for Brazil [69][115][116][117][118][119][120][121][122] and vinasse from corn and cassava [123]. The biogas generated by the AD of vinasse can also be used as vehicular biofuel.

More recently, in the in the Metropolitan Region of the city Ribeirão Preto, the Companies Raizen and Geo Energética, merged to construct the first AD plant that will treat vinasse together with filter cake, attempting to prove the viability of such projects [124]. Also in the city of Pirapozinho there is a project in development to supply the city by 2020 with biomethane produced with vinasse and other sugarcane residues [125].

Additionally, in the state of Paraná, the first large-scale combined biogas plant from organic solid wastes and sewage is under development, which will treat about 1,000 m3 of sewage and 300 tons of organic residues. The plant will provide $2.8 \mathrm{MW}$ of electric power, which will be then distributed to about 2,000 households. [126]. Also, a dry AD plant is under construction by the German Company Bekon, in Sao Paulo with a capacity of 10,000 t/a, and an electrical power of $190 \mathrm{~kW}$ [100].

As for methanization via dry anaerobic digestion, and considering the successful experiences in Europe, these technologies have been lately called the attention of some LAC countries. 
However, there are still some characteristics in the region that inhibit the implementation of such projects (with exception of the case in Mexico in Sinaloa and Sao Paulo, Brazil under construction). Lack of selective collection and waste mixtures with improper materials are some of the barriers to implement such technologies [127]. On the other hand, nowadays European firms are the main developers of such technologies, which difficult their implementation in the region due to high materials and importation costs, reducing the economic feasibility of such projects.

Nevertheless, for example in Brazil, by initiative of the company "Methanum Resíduo e Energia" and The Federal University of Mina Gerais (UFMG), there has been in consideration the development of a dry anaerobic digester for the treatment of the OFMSW, adequate to the particular conditions of Brazil [127]. Also in Rio de Janeiro, an extra-dry methanization system for treating organic waste is currently being implemented as a demo-scale plant to study the storage strategies, treatment and uses of the biogas generated [128].

\subsubsection{Co-digestion \& Biochemical Methane Potential (BMP)}

Research in the region has also shown the importance of co-digestion to improve performances of biodigestion processes. For example Alvarez and Lidén (2008) [129], found out these advantages in Bolivia with an experiment mixing residues such as quinoa stalk residues, totora (Schoenoplectus californicus subsp.tatora) and aquatic flora from Lake Titicaca, with manure from Ilama, cow and sheep. The use of totora resulted to considerable increase up to $130 \%$ the methane yields. Or the research by Santibañez et al., (2011) [130] determined the potential of residual glycerol as a co-digestate for anaerobic digestion processes. In Argentina, co-digestion of poultry manure with vegetable and fruit waste was tested in a continuous stirred tank (CSTR) at a bench scale. It was found that the presence of food waste improved the biogas and methane yield by more than $31 \%$ by the increase of $\mathrm{C} / \mathrm{N}$ ratio and the dilution of nitrogen compounds. In terms of digestate quality, toxicity was associated to the salinity, total elements and nitrogen compounds. Digestate obtained by mono-digestion of poultry manure resulted in high $\mathrm{Na}, \mathrm{EC}, \mathrm{Mn}$ and $\mathrm{Zn}$ concentrations [131].

In Colombia, co-digestion of a mixture of cocoa industry residues (CIR), pig manure (PM) and organic fraction of municipal solid waste (MSW), resulted in high methane production $(2,485.91 \mathrm{~mL} \mathrm{CH4/gr} \mathrm{Vs)} \mathrm{according} \mathrm{to} \mathrm{the} \mathrm{experiments} \mathrm{developed} \mathrm{by} \mathrm{Rodríguez} \mathrm{et} \mathrm{al.} \mathrm{(2017)}$ [132]. However, other research has proven that co-digestion not always promotes higher 
biogas production rates. For example in the case of an experiment in Peru by Garfi et al., (2011) [70] the co-digestion of guinea pig manure and cow manure did not improve biogas yields.

Several other works e.g. [133][134] confirm the importance of Biochemical Methane Potential (BMP) test, for the evaluation and selection of residues to be treated via Anaerobic Digestion; however as stated by Cárdenas Cleves et al. (2016) [135] it is a priority to define an standardize methodology to measure BMP in the region. This will allow for the liability of the results and reproducibility of experiments.

\subsubsection{Fermentation}

Fermentation is the process by which organic material is converted into alcohol, gas or acids (e.g. bioethanol, lactic acid, biodiesel, biohydrogen, etc.), in the absence of oxygen and done by selective cultures of anaerobic microorganisms, leaving a nutrient-rich residue. The fermentation industries that produce biofuels, have recently shown continuous growth in various countries in the American continent [136]. Bioethanol, for example, is Brazil's one of the most prominent products, with a production and utilization of this biofuel from sugarcane for more than 30 years [137]. Argentina together with Brazil are also experiencing the emerging utilization of soy beans for biodiesel production, and together with Colombia are the only countries in the region with established biofuel markets [138]. Furthermore, there are also various other countries in the region that have shown interest or have already implemented, in less extent, projects on the production of biofuels [137]. For example, in Uruguay, the goal of incorporation of $5 \%$ of liquid biofuels into gasoline and diesel oil was recently achieved [105]. Or in Ecuador where this same goal is in process to be met, following a recent governmental mandate and a bioethanol production of 80 million liters [139]. Furthermore, having Latin America around 17\% of total primary energy supply (TPES) from biomass (Walsh, 2004 in Garcia M. et al., (2012) [140], the region has great potential to increase this share and become one of the major global producers of bioenergy.

Contrastingly, even when first generation (1G) biofuel production represent a viable and convenient alternative for the substitution of fossil fuels in the region, there are recent concerns related to their economic, social and environmental viability as energy sources [141][142]. Among various reasons, the fact that the production of these commodities is compromising food and feed production using arable and fertile lands is making decision 
makers look into other energy source options. Hence, the efficient utilization of forestry and agricultural wastes and residues that do not compete with food production is becoming increasingly important; not only to minimize the environmental and social impacts, but also to increase economic profitability [143], with the production of the so called second generation $(2 \mathrm{G}$ ) biofuels. The inclusion of $2 \mathrm{G}$ biorefinery has been lately gaining ground and interest in various countries of the region, considering the existent great biomass potential from the generated residues. Hereafter a general description of the current state of the art of the existent $2 \mathrm{G}$ technologies and research in the region.

\subsubsection{Bioethanol and Biodiesel}

In the Caribbean Islands, bioethanol production from waste materials is still in its infancy stage [7]. Exceptionally, ethanol industry in Jamaica is at advance stage, dealing mainly with the conversion of hydrous into anhydrous ethanol [144]. In the rest of the Islands these technologies are practically non-existent at industrial scales [7]. In Belize, recently the Organization of American States (OAS) has executed an assessment to identify waste streams within the forestry, agricultural and waste management sectors to evaluate their potential as feedstock for bioethanol production. The results envisioned a considerable potential for a cellulosic ethanol market [145].

Considering the large production rates of palm oil, maize and sugarcane, Central America has potential to build a strong biofuel industry. Presently, the region has 23 biofuel plants (bioethanol and biodiesel), mainly using molasses from sugarcane, which is a by-product of the sugar crystallization process and African palm. However, there is still no biofuel market in the region [8].

LAC is the region with the most production of coffee worldwide, with Colombia and Brazil being the leading producers [146]. These result as potential candidates for bioenergy production due to their high cellulose and hemicellulose content, high calorific value and low ash content [147].

Also in Colombia, palm is one of the most important oleo-chemical feedstock [141]. Its processing palm oil extraction lead to the formation of several by-products and residues that can be transformed into value added products in a cleaner way and have energy and economical potential. Currently, palm is used for biodiesel production and eight biodiesel 
plants are working. The empty fruit bunches (EFB) is the solid residue with the highest production amount. Other residue is the glycerol resulted from the process to produce biodiesel [141]. Along with Colombia, Palm oil plantations have been lately also growing in countries such as Brazil, Guatemala, Ecuador and Peru; however this plantations boom is also threatening the rights of local communities and putting forests and ecosystems at risk [148].

Large amounts of banana residues (skin, stalks and steams) are also generated in the region. Being Brazil, Ecuador, Costa Rica, México and Colombia some of the largest producers of this fruit, there is an important potential of using these residues as a bioenergy source to produce bioethanol in the region [147][149][150][151][152]. However in 2015, the study by Rambo et al. [147], questioned this potential stating that these residues are not entirely suitable for bioenergy production due to the high moisture content that prevents their transportation, in addition to the high extractive content and low calorific value. Research is advised by Velásquez-Arredondo et al. (2010) [149], with the aim of optimizing the variables affecting the process performance, such as temperature, reaction time, the water used in hydrolysis for a more efficient bioethanol production.

Currently, in 1G-bioethanol plants, large amounts of sugarcane bagasse are produced when the juice is separated from the fiber. In LAC countries, this bagasse is usually burnt in low efficient cogeneration systems to produce steam and electricity for the plant and in some cases generate surplus electricity to be sold, thus improving the revenues of the enterprises. Occasionally, also the sugarcane trash from the plantation fields is also collected and increases the electricity production (even when around $50 \%$ of the generated trash must remain on the fields in order to provide weed control and nutrient recycling).

Nevertheless, late research has been proving the low efficiency of these combustion systems and that bagasse could be of better use by converting it into fermentable sugars through pretreatment and hydrolysis processes to obtain bioethanol [153]. Diverse studies e.g. [150][153][154][155][156] have concluded that 2G bioethanol could positively compete with $1 \mathrm{G}$ production when sugarcane field trash is partially used and when low cost enzyme and more efficient technologies become commercially available.

However, the application of such projects has still some constraints and challenges. For example Wang et al. (2014) [157], states that the $1 G+2 G$ bioethanol pathway remains less economically favorable than the $1 \mathrm{G}$ bioethanol pathway and suggests that with the current 
technical and economic conditions, it is more favorable to use sugarcane bagasse and trash for generating electricity via combustion. The author mentions that $2 \mathrm{G}$ could become competitive in the prospective 2020 scenario, when a series of technology challenges are overcome, which shall help to reduce production cost to $0.31 \$ / \mathrm{L}$.

In Brazil, the two plants evidencing viable production of cellulosic bioethanol from sugarcane bagasse and straw have showed optimistic projection on this path. The GranBio power plant installed in São Miguel dos Campos, Alagoas (using bagasse and straw) and Raizen in Piracicaba, São Paulo (using bagasse). Raizen is already successfully producing $2 \mathrm{G}$ bioethanol on a commercial scale [158]. This process is, however, at the beginning of its technological learning curve [156].

Additionally, Avelino Gonçalves et al. (2015) [158] also proposes, besides the production of $2 \mathrm{G}$ bioethanol in large scale plants, the implementation of power plants of medium and small size, specially microdistilaries, with a capacity of up to 5000 liters. The distribution of these type of technologies throughout the region will lead to gain social, environmental and economic benefits, and avoid some of the difficulties encountered to produce bioethanol from straw and bagasse from sugarcane in industrial scale.

There are also expanding research efforts in Mexico to use bagasse residues from the tequila industry for the production of biofuels, at the same time propitiating their correct disposal [159][160][161].

Aside of the mentioned residues from the main crop plantations, biofuel production from other biomass residues should be accounted for. Various residues have been identified for their renewable resource potential such as rice husks, açai seed, eucalyptus sawdust, coconut husks, elephant grass, bamboo, soy peels [147], legumes: alfalfa and clovers [162], eucalyptus bark [163], maize "Luteño" [164], brewer's spent grains (BSG) [165], and grape wine waste [166]. Fruit peels have been also envisaged as potential biofuel feedstocks in LAC [167][168]. Bioethanol production potential was also deduced from various lignocellulosic materials (sugarcane bagasse (SCB), empty fruit bunches (EFB), rice husk (RH) and coffee cut-stems (CCS) [169]. 


\subsubsection{Biohydrogen and biomethanol}

Other technique that seems to be attractive for the proper treatment of organic wastes and clean energy generation in the region is biohydrogen $(\mathrm{H} 2)$ production via dark fermentation. Results of various studies demonstrated fermentation of agro wastes as an attractive and feasible technique to generate biohydrogen. For example in Mexico, [170] $\mathrm{H}_{2}$ production was analyzed in batch fermentation of a substrate that consisted of a mixture of sugarcane bagasse, pineapple peelings, and waste activated sludge, or Posso et al., (2017) in Ecuador proposed the use of the $\mathrm{H}_{2}$ derived from the OFMSW as an energy source for transportation [171].

As for the production of biomethanol in the region from organic residues, being $\mathrm{CO}_{2}$, an inevitable residue from combustion and other processes, recently attention has been put into the option of hydrogenating it for its chemical transformation into biomethanol. In Brazil, this has been attractive and relatively easy to implement in the short-to-medium terms [172]. However, the low reactivity of $\mathrm{CO}_{2}$ and the thermodynamic limitations remain challenges to be overcome in the development of sustainable $\mathrm{CO}_{2}$ conversion processes [172].

\subsubsection{Landfilling with gas capture}

In LAC most of the solid waste is destined to landfills and dumps. More precisely, $83 \%$ of the total waste produced in the region in 2011 [173]. Landfilling is highly practiced in most countries of the region, due to that it is the cheapest management technique and is easier to be built by municipalities, compared to other management alternatives [174]. Yet, many of them are poorly sited and improperly managed and are not sanitary [175]. At the same time, there are some examples of well-managed sanitary landfills in the region where aside of a proper final disposal of waste, there is generation of energy as result of the decomposition processes.

Until 2011 more than 99 waste-to-energy landfills projects had been approved and financed just in the Latin American region [173], through carbon markets associated with the Clean Development Mechanism (CDM), resulting in the reduction of more than 19 million tons of CO2 equivalent from 2007 to 2012 [176]. Brazil and Mexico are among the five countries worldwide that receive more carbon incomes by means of the Certified Emissions Reductions (CERs), mainly due to their biomass to biogas projects in landfills [16]. 
In the case of the Caribbean Islands, some successful cases and proposals were detected. For example in Mauritius, there is a landfill with a surface area of 224,990 $\mathrm{m} 2$ where wastes are properly disposed with the power capacity of 3.3 MW [177]. In the US Virgin Islands there is a landfill gas and electricity generation plant, generating some $815 \mathrm{~kW}$, which is sufficient for powering 900 homes approx. [178]. In the region, other countries like Bahamas, St. Lucia [179], St. Vincent and the Grenadines [180] and Grenada [181], have also demonstrated interest to implement landfill gas capture projects. The implementation of efficient technologies for waste treatment and volume reduction is becoming increasingly important in the Islands, considering the lack of locations for solid waste disposal and the pollution caused by traditional disposal methods [7].

In the city of Monterrey, Mexico, the first waste to energy landfill project was implemented in 1990 and proved to be successful, that other cities in Mexico have since replicated the approach. Today, the energy produced from 19 million tons of waste landfilled annually, is turned into electricity (16 MW power capacity) that moves its subway and provides safer streets through public lighting, while at the same time shrinking municipalities' operating costs and reducing GHG emissions [173].

Other cities in LAC have also installed similar systems. For example the city of Maldonado in Uruguay biogas is captured from landfills, capable of producing more than $550 \mathrm{~kW}$ [173]. Here, the Ministry of Environment of Uruguay detected that this technologies carry a heavy financial burden when it serves small populations. Accordingly, as stipulated by [173] cities with a population over 100,000 inhabitants seem to be the most appropriate for implementing landfilling waste to energy systems. Also in Chile, an important part of biogas from biomass is obtained from landfills [75][182]. In Colombia, the landfill of "Doña Juana" produce electricity from the generated biogas with an installed capacity of 1,7 MW. Another power plant is being constructed to generate electricity for 25,000 people from the landfill of Guayabal, located in Cucuta, Colombia.

In the case of Brazil, the use of landfill gas (LFG) for electricity production is well implemented and increasing. In São Paulo, for example, there are two landfills where LFG has been used to produce electricity [23]. Further, the first experiences in the region of using the biogas for the urban bus fleet have begun in Campinas' city, involving the sanitary landfill of Santa Barbara [183]. At the same time, other studies found out that the biogas obtained from 
landfills can also significantly contribute to the energy matrix of Brazil [184]. Since July 2017 in Brazil, the use of methane obtained from landfill is already regulated for its commercialization as a vehicle fuel and have the same natural use than natural gas [185]. It is expected that in the upcoming years biogas and biomethane will play a major role in the energy matrix of the country [186]. Also in the state of Ceará, the Gas State Company Cegas is already injecting $15 \%$ of biomethane in its comercialezed natural gas system [187].

Moreover, even when landfilling is still seen as a viable option since is the technology that presents minor costs and there is land around the big cities for its implementation, there is currently an ongoing debate on whether this treatment method should prevail in the region in comparison to other thermal and biochemical treatment technologies, which have been implemented in most developed nations for several decades [23]. According to EscamillaAlvarado (2017) [188], landfilling is expected to be replaced by environmentally sound management options in the region.

In line with this, some countries in LAC are already closing their dumpsites, for example in Buenos Aires, an open dump that occupied an area of 8 hectares for 20 years was recently closed [189]. Or the case of the dumpsite in Brasilia, which served between 4 to 5 million people, has been already partially closed, being the waste now dumped in a new sanitary landfill, which opened in early 2017. The city is also currently building a number of sorting and recycling plants, where waste is intended to be properly treated [190]. In Mexico City the largest rubbish dump was closed in 2011 [191].

Hence, even when several studies and projects in LAC have demonstrated the benefits of MSW landfilling with gas capturing in the region, just in the last decade there have been some perception changes towards the implementation of thermochemical or anaerobic digestion in view of the technical and environmental advantages they offer.

\subsubsection{Microbial fuel cell (MFC)}

In the LAC countries, the development of Microbial fuel cell (MFC) projects is at research level, with some studies highlighting the potential they may have in the region. For instance, in the study by Tota-Maharaj and Paul (2015) [192], two identical laboratory-scaled MFC systems were designed and tested for the Caribbean regional context. Results demonstrate the ideal implementation of these technologies in the Islands. Likewise, in Mexico, another 
study [193], concluded that the application of MFC for municipal wastewaters and landfill leachate is promising for effluent depuration and bioenergy generation. The authors recommend further investigation. In South America, research by Rachinski et al., (2010) [194] in Brazil also presented MFC as a favorable technology for the utilization of animal and vegetable solid wastes, as an alternative to waste remediation, and electricity and fertilizer production.

\section{GENERAL CHALLENGES AND OPPORTUNITIES}

\subsection{Challenges}

In general, the identified challenges $L A C$ region is facing for an adequate implementation of OWtE technologies are classified mainly as institutional, financial, technical and educational, as hereafter mentioned:

- Dearth or ineffectiveness of waste management strategies, which require the balancing of optimized waste reduction practices, recycling, recovery, and landfilling [145] [7], together with educational and technical programs;

- Lack or deficient institutional frameworks, environmental legislation [50] and business models [110].

- Adopt new markets (such as the free electricity market and micro generation) for this potential energy source, and the creation of public incentive policies for their implementation [195].

- High technology costs for the equipment and maintenance.

- Low or no financial incentives to facilitate energy generation from wastes and the implementation of modern waste management strategies [145];

- Lack of reliable and relevant information on urban waste (i.e., amount of waste, waste composition, and potential uses of collected waste), or agricultural residues (i.e., quantities, types, BMP's, etc.) according to the situation in each country [145];

- In many countries of the region there is a dearth of engineering companies, manufacturing equipment, and a prevailing low state of technology that has limited the region's capacity to implement OWtE [8]. 
- Other of the major problems in the region is the absence or limited knowhow, capabilities and expertise on the existing technologies [7]; and furthermore research and development for new and appropriated technologies.

- Research to prove the competitiveness of bioenergy production compared to fossil fuels [50].

In LAC, one of the main challenges identified, and pointed out by various authors [44][112] [185] is to find the economic feasibility of the projects, considering the high technology, production and maintenance costs involved. The costs from generating biofuels or biogas in the region from residues are, in general, still higher than the fossil fuels resources tariff currently in the market [110]. The development of technologies that are economically feasible for the region is transcendental for OWtE to thrive.

Having in mind that OWtE systems represent a part of an integrated waste management strategy and are not always the most sustainable solution, particular analysis should be carried out for the evaluation on which technology should be better. Further research is also required to proper seek for the contributions these technologies can provide to reduce emissions and for the viability to implement and diffuse WtE technologies to promote sustainable energy systems in the region.

\subsection{Opportunities}

The utilization of organic wastes to produce energy in LAC has been lately enhance by the series of environmental, technical and economic opportunities and benefits offered by their implementation, which are plentiful and have been demonstrated by diverse researches and projects. These opportunities have been lately expanding and arising interest in the region due to the benefits associated with the implementation of these technologies. Hereafter a series of identified opportunities in the region.

\subsubsection{Environmental opportunities}

- The implementation of these technologies could contribute to face the multiple problems derived from the disposal of solid waste in sanitary landfills and dumpsites;

- Accordingly, the countries in the region could also benefit from OWtE technologies to attain national goals of GHG reduction established by the Nationally Determined 
Contributions (NDC's) under the new international agreement adopted in December 2015, in Paris [196].

\subsubsection{Social opportunities}

- Beyond improving the sustainability on each country, the production of bioenergy with waste will also help to improve energy security, diversify their national energy mix and reduce diesel fuel imports [171].

- Harnessing the potential from residual biomass would also enhance the development and wellbeing of the rural communities, not affecting their food security [151], and further bringing the much needed employment in the rural areas.

- Public health will also be beneficiated, reducing pollutants in the environment.

- Create new alliances between engineering companies or firms and academic units, which will allow for a mutual improvement, and gain technical experiences regarding new Technologies [8].

\subsubsection{Economic opportunities}

- Increase the revenues generated by the utilization of residues or byproducts that are usually discarded by large enterprises;

- The economic use of residual biomass in rural areas could generate an extra income to the small farmers of the region and enhance their development. [151].

- The increase on prices of fossil fuels is slowing the economic development of many small countries in LAC, for which waste-to-energy alternatives are very attractive throughout the region.

\section{KEY FINDINGS AND CONCLUDING REMARKS}

In LAC, every year millions of tonnes of agricultural forest and urban solid residues are generated. Their potential as alternative energy sources through biochemical and thermochemical processes has been identified. In recent years, various small and large-scale projects have occurred and several studies have presented technical, environmental and economic analyses of different technologies in the region, as well as their comparative performances for bioenergy production. Hereby the key aspects and highlights identified on the state of the art of OWtE in LAC though this literature review. 


\subsection{Thermochemical}

Among the main thermochemical technologies, incineration is the most commonly practiced in LAC [7][8] with a demonstrated further potential. Nevertheless, nowadays there is an ongoing debate on whether this is the right organic waste treatment method, considering the environmental drawbacks and low process efficiency these technologies portray. Gasification and pyrolysis present some advantages over combustion such as being more thermally efficient, utilization of downstream products (biofuels, chemical or fertilizers), and higher and cleaner bioenergy production, among others [10].

\subsubsection{Key findings:}

- Combustion technologies have been widely applied in LAC, for agricultural and forest residues to produce electricity, considering that it is still the least cost thermochemical option [18]. Sugarcane bagasse and straw are the main combusted residues [8].

- Diverse densification techniques have been applied in the region, such as pelletizing, briquetting and torrefaction, which are intended to achieve adequate properties and higher calorific values. Today, Argentina, Brazil, Chile, Costa Rica, Honduras, Mexico and Uruguay [28] produce pellets at industrial level for national markets. LAC accounts for a large potential to palletize and export agricultural and wood residues.

- Diverse experimentation indicates that gasification has ideal characteristics for producing energy in LAC. Gasification systems have been implemented in countries like Cuba [8] and Brazil [50], which are seen as valuable experiences for further transfer of technologies. In other countries in LAC, gasification has been proposed or is in development phase as a waste management technology and generation of energy (heat, hydrogen, ethanol and electricity).

- Even when pyrolysis is the least thermochemical technology practiced in the region [7][8], various researches have demonstrated it as an efficient technology to treat OW and produce renewable fuels in the region. However in Central America, for example, pyrolysis is deduced to be the least preferable technology [8]. Further studies are necessary to understand more on the economics and logistics of the process [32]. 


\subsection{Biochemical}

Biochemical technologies comprehend anaerobic digestion, fermentation, landfilling gas capture and Microbial fuel cell (MFC) technologies. In recent years, R\&D on biochemical treatment of organic residues in LAC has been focused in small-scale anaerobic digesters (AD) [9] and landfilling; and fermentation in less extent. Notwithstanding, interest in large-scale biodigesters, second generation biofuels and MFC's has been gaining ground in the last years with some countries in LAC already implementing such projects.

\subsubsection{Key findings:}

- Low-cost household biodigesters have been successfully implemented in rural zones throughout LAC and are proved as an appropriate technology to treat agricultural residues, produce fertilizers and energy. However, according to Garfí et al. 2016 [9], there are still several barriers to overcome in order to improve and further disseminate the technology.

- Large-scale AD have not been widely implemented in the region mainly due to their high investment costs, systems technical complexity and high maintenance demands [1]. However, Argentina, Chile and Brazil, have implemented more than a dozen of Continuous Stirred Tank Reactors (CSTR), Upflow Anaerobic Sludge Blanket (UASB) and cover lagoons. Other countries have similar experiences in less extent. Full-scale dry AD has been implemented in Brazil and Mexico.

- Significant research in the region has evaluated the benefits of co-digestion and Biochemical Methane Potential (BMP) tests to improve performances of biodigestion processes.

- Currently, the fermentation industries that produce first generation (1G) biofuels have shown continuous growth in various countries in LAC. Only Argentina, Brazil and Colombia have established biofuel markets.

- The inclusion of $2 \mathrm{G}$ biorefinery is lately gaining ground in LAC. R\&D is developing on the potential of residues from diverse crops such as sugarcane, coffee, corn, banana, palm oil, rice, etc. However, the application of such projects has still some constraints and challenges, such as the technology readiness, or the profit-earning capacity. In Brazil, optimistic projection on the $2 \mathrm{G}$ paths has been shown by the two plants' 
GranBio and Raizen. Raizen currently produces bioethanol from sugarcane bagasse and straw.

- Biohydrogen production via dark fermentation is gaining attention in the region, with proposals to use the OFMSW and other residues as feedstock.

- In LAC, 83\% of the total waste produced in the region was destined to landfills and dumps in 2011. By then more than 99 WtE landfills projects were approved and financed in the region, by the Clean Development Mechanism (CDM) [173]. Brazil and Mexico are among the five countries worldwide that receive more carbon incomes.

- Some countries in LAC are already closing their dumpsites. For example Buenos Aires, Brasilia and Mexico City. These cities are changing towards the implementation of thermochemical or $A D$ in view of their technical and environmental advantages.

- Microbial fuel cell (MFC) technology in LAC is at research level; with some studies highlighting the potential they may have in the region.

\subsection{Concluding remarks}

In recent years, various small and large-scale OWtE projects have been implemented, and several studies have presented environmental and technical analyses of different OWtE technologies in LAC. Currently, there is an ongoing debate on which of these is the most adequate technique to treat organic residues because of their energy potential. Throughout this literature review, we found out that OWtE technologies are not always the most adequate option and the benefits of keeping agricultural residues on the fields cannot be neglected.

The answer to the feasibility on the implementation of one technology over the other for each residue is not set in stone but rather depends on each country conditions and mainly on market and technological factors. Therefore, genuine analyses and studies shall be carried out for each unique case. The review of the state of the art of these technologies resulted that anaerobic digestion and gasification are deemed as the two most promising technologies, in view of the technical and environmental advantages they offer.

Furthermore, it was recognized that the implementation of OWtE technologies will be crucial for the sustainable development of LAC and to significantly contribute to improve waste and energy systems along with a number of social and economic benefits. Further works shall 
keep determining the bioenergy production potential for the diverse organic residues and demonstrate the applicability of small and large-scale OWtE treatment plants throughout the Latin-American and Caribbean region.

Table 2: Summary of the content analysis and its coded references

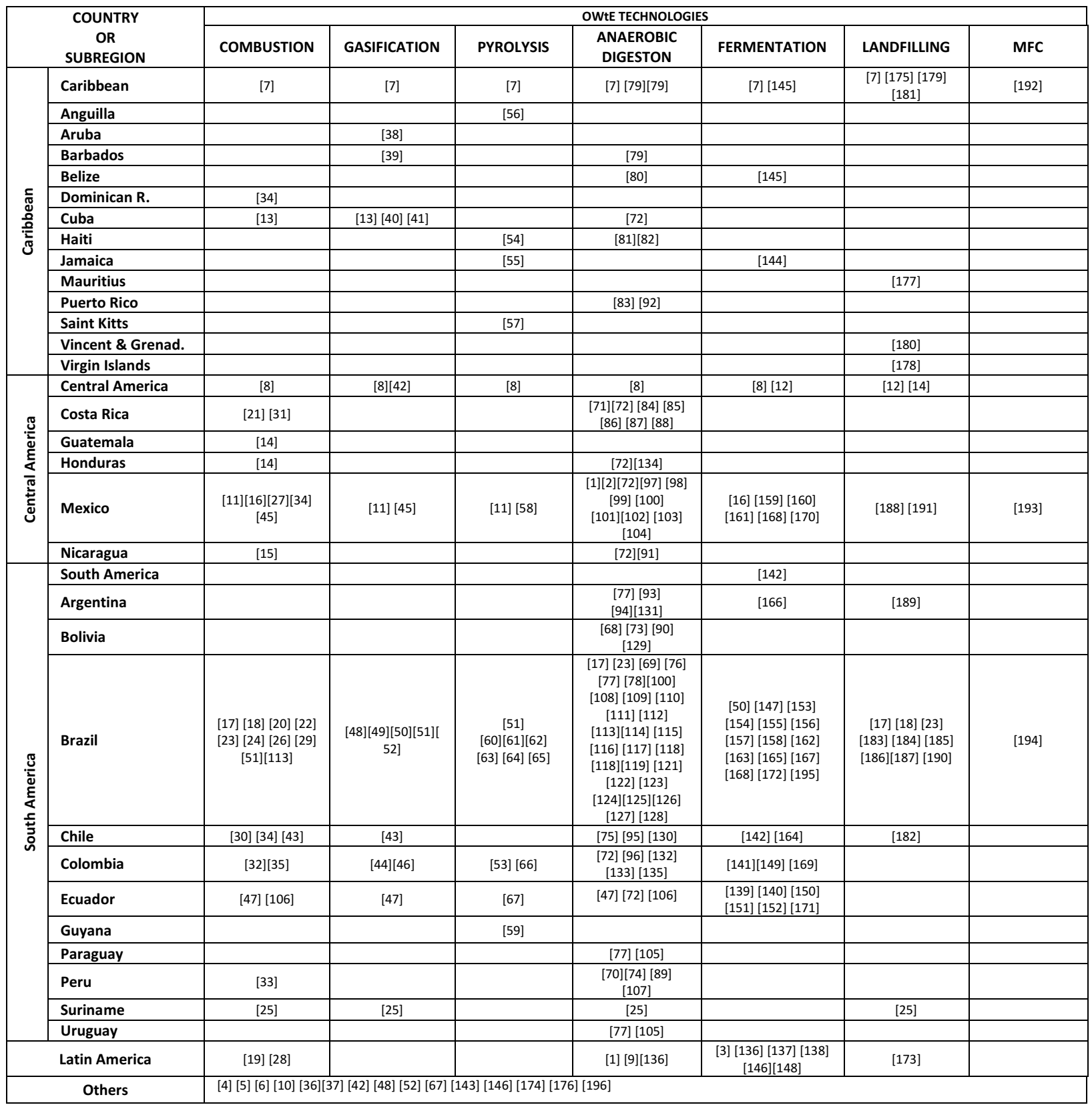

\section{Acknowledgements}

This work was supported by funding from The National Council on Science and Technology (CONACYT), Mexico; and the Postgraduate Support Program, of the Coordination for the Improvement of Higher Education Personnel (CAPES), Brazil. 


\section{REFERENCES}

[1]J. Martí-Herrero, M. Pino, L. Gallo-Mendoza, G. X. Pedraza, L. Rodríguez, and J. Víquez, Oportunidades para el desarrollo de un sector sostenible de biodigestores de pequeña y mediana escala en LAC. 2016.

[2]J. Koldisevs, J. Alberto, and R. Gonzales, "Biogas production in rural areas of Mexico," 2014.

[3] UNEP, "Towards sustainable production and use of resources: Assessing Biofuels," 2008.

[4]D. L. Searcy and J. T. Mentzer, "A Framework for Conducting and Evaluating Research," J. Account. Lit., vol. 22, no. 07374607, pp. 130-167, 2003.

[5] K. A. Neuendorf, The Content Analysis Guidebook, 2nd ed. Los Angeles: SAGE Publications, Inc., 2017.

[6] World Energy Council, "World Energy Resources: Waste to Energy," 2016.

[7] R. Mohee, S. Mauthoor, Z. M. A. Bundhoo, G. Somaroo, N. Soobhany, and S. Gunasee, "Current status of solid waste management in small island developing states: A review," Waste Manag., vol. 43, pp. 539-549, 2015.

[8] L. Cutz, P. Haro, D. Santana, and F. Johnsson, "Assessment of biomass energy sources and technologies: The case of Central America," Renew. Sustain. Energy Rev., vol. 58, pp. 1411-1431, 2016.

[9] M. Garfí, J. Martí-Herrero, A. Garwood, and I. Ferrer, "Household anaerobic digesters for biogas production in Latin America: A review," Renew. Sustain. Energy Rev., vol. 60, no. July, pp. 599-614, 2016.

[10] GSTC, "Gasification vs. Incineration," 2018. [Online]. Available: https://www.globalsyngas.org/applications/gasification-vs-incineration/. [Accessed: 18-Apr-2018].

[11] M. M. Parascanu, F. Sandoval-Salas, G. Soreanu, J. L. Valverde, and L. Sanchez-Silva, "Valorization of Mexican biomasses through pyrolysis, combustion and gasification processes," Renew. Sustain. Energy Rev., vol. 71, no. December 2016, pp. 509-522, 
2017.

[12] CEPAL, "Informe de la reunión de expertos sobre la situación de la biomasa en países de centroamérica y el caribe y evaluación del potencial para su aprovechamiento energético," vol. 1233, 2017.

[13] G. Bruzos-Bonzon and J. Mirabent-Avila, "La utilización de 'Residuos Sólidos' con fines de generación eléctrica. Una alternativa favorable al medio ambiente," 2005.

[14] CEPAL, "Energy Efficiency in Central America: Progress and Action towards the fulfillment of the goals of the Central American Sustainable Energy Strategy," 2014.

[15] Proparco - Groupe Agence Française de Développement, "A loan to support responsible sugar production in Nicaragua," 2018. [Online]. Available: http://www.proparco.fr/en/suganc. [Accessed: 12-Oct-2018].

[16] G. S. Alemán-Nava et al., "Bioenergy in Mexico: Status and perspective," Biofuels, Bioprod. Biorefining, vol. 9, no. 1, pp. 8-20, Jan. 2015.

[17] J. Portugal-Pereira, R. Soria, R. Rathmann, R. Schaeffer, and A. Szklo, "Agricultural and agro-industrial residues-to-energy: Techno-economic and environmental assessment in Brazil," Biomass and Bioenergy, vol. 81, pp. 521-533, 2015.

[18] G. A. Dantas, L. F. L. Legey, and A. Mazzone, "Energy from sugarcane bagasse in Brazil: An assessment of the productivity and cost of different technological routes," Renewable and Sustainable Energy Reviews, vol. 21. pp. 356-364, 2013.

[19] D. Thrän, Global Wood Pellet Industry and Trade Study 2017, no. June. 2017.

[20] Ambiente Energia, "Mato Grosso do Sul terá termelétrica que funcionará com biomassa de eucalipto," Biomassa e Bioenergia, 2018. [Online]. Available: https://www.biomassabioenergia.com.br/imprensa/mato-grosso-do-sul-teratermeletrica-que-funcionara-com-biomassa-de-eucalipto/20180205-100014-K995. [Accessed: 20-Aug-2018].

[21] S. Aragón-Garita, R. Moya, B. Bond, J. Valaert, and M. Tomazello Filho, "Production and quality analysis of pellets manufactured from five potential energy crops in the Northern Region of Costa Rica," Biomass and Bioenergy, vol. 87, pp. 84-95, 2016.

[22] J. G. C. Balcazar, R. A. Dias, and J. A. P. Balestieri, "Analysis of hybrid waste-to-energy 
for medium-sized cities," Energy, vol. 55, pp. 728-741, 2013.

[23] S. N. M. De Souza, M. Horttanainen, J. Antonelli, O. Klaus, C. A. Lindino, and C. E. C. Nogueira, "Technical potential of electricity production from municipal solid waste disposed in the biggest cities in Brazil: Landfill gas, biogas and thermal treatment," Waste Manag. Res., vol. 32, no. 10, pp. 1015-1023, 2014.

[24] G. H. Nordi, R. Palacios-Bereche, A. G. Gallego, and S. A. Nebra, "Electricity production from municipal solid waste in Brazil," Waste Manag. Res., vol. 35, no. 7, pp. 709-720, 2017.

[25] L. F. Zuilen, "Planning of an Integrated Solid Waste Management System in Suriname: A Case Study in Greater Paramaribo with Focus on Households. Thesis (PhD), Ghent University," p. 366, 2006.

[26] M. V. Scatolino et al., "Options for Generation of Sustainable Energy: Production of Pellets Based on Combinations Between Lignocellulosic Biomasses," Waste and Biomass Valorization, vol. 0, no. 0, pp. 1-11, 2017.

[27] M. Moreno-Lopez, M. T. Alarcón-Herrera, and I. R. Martin-Dominguez, "Feasibility of Pelletizing Forest Residues in Northern Mexico," Waste and Biomass Valorization, vol. 8, no. 3, pp. 923-932, 2017.

[28] FAO, "Forestry Production and Trade," FAOSTAT, 2016. [Online]. Available: http://www.fao.org/faostat/en/\#data/FO. [Accessed: 14-Sep-2018].

[29] J. F. Escobar, "A produção sustentável de biomassa florestal para energia no Brasil: O caso dos pellets de madeira," p. 122, 2016.

[30] UDT, "MMA - Ministerio del Medio Ambiente; Producción de pellets en Chile y tecnologías de combustion.," 2013. [Online]. Available: http://portal.mma.gob.cl/. [Accessed: 03-Feb-2018].

[31] J. Gaitán-Álvarez and R. Moya, "Characteristics and properties of torrefied biomass pellets from Gmelina arborea and Dipterix panamensis at different times," Rev. Chapingo, Ser. Ciencias For. y del Ambient., vol. 22, no. 3, pp. 325-337, 2016.

[32] J. F. Pérez, M. R. Pelaez-Samaniego, and M. Garcia-Perez, "Torrefaction of FastGrowing Colombian Wood Species," Waste and Biomass Valorization, vol. 0, no. 0, pp. 
1-13, 2017.

[33] M. Alarcon, C. Santos, M. Cevallos, R. Eyzaguirre, and S. Ponce, "Study of the Mechanical and Energetic Properties of Pellets Produce from Agricultural Biomass of Quinoa, Beans, Oat, Cattail and Wheat," Waste and Biomass Valorization, vol. 8, no. 8, pp. 2881-2888, 2017.

[34] F. Sánchez, K. Araus, M. P. Domínguez, and G. S. Miguel, "Thermochemical Transformation of Residual Avocado Seeds: Torrefaction and Carbonization," Waste and Biomass Valorization, vol. 8, no. 7, pp. 2495-2510, 2017.

[35] G. Marrugo, C. F. Valdés, C. Gómez, and F. Chejne, "Pelletizing of Colombian agroindustrial biomasses with crude glycerol," Renew. Energy, vol. 134, pp. 558-568, 2019.

[36] A. Molino, S. Chianese, and D. Musmarra, "Biomass gasification technology: The state of the art overview," J. Energy Chem., vol. 25, pp. 10-25, 2015.

[37] A. V Bridgwater, "Renewable fuels and chemicals by thermal processing of biomass," Chem. Eng. J., vol. 91, pp. 87-102, 2003.

[38] S. Whippy, "Power Plant Turns to Pyrolysis," The Fiji Times Online, 2011. [Online]. Available: http://www.wastaway.ca/. [Accessed: 05-Apr-2018].

[39] Waste Management World, "240m-plasma-gasification-waste-to-energy-deal-signedin-barbados @ waste-management-world.com," 2014. [Online]. Available: https://waste-management-world.com/a/240m-plasma-gasification-waste-to-energydeal-signed-in-barbados. [Accessed: 15-Jun-2018].

[40] O. L. Jimenez, "Cuba's first biomass gasification technology installed | Gasifiers," 2010. [Online]. Available: http://gasifiers.bioenergylists.org/cubaenergia. [Accessed: 04-Apr2018].

[41] UNIDO, "Biomass gasification can power off-grid areas in Cuba," 2015. [Online]. Available: https://www.unido.org/news/biomass-gasification-can-power-grid-areascuba. [Accessed: 28-May-2018].

[42] C. Higman, "State of the Gasification Industry - the Updated Worldwide Gasification Database," 2013.

[43] C. Román-Figueroa, N. Montenegro, M. Paneque, C. An Rom An-Figueroa, N. 
Montenegro, and M. Paneque, "Bioenergy potential from crop residue biomass in Araucania Region of Chile," Renew. Energy, vol. 102, pp. 170-177, 2017.

[44] C. A. García, J. Moncada, V. Aristizábal, and C. A. Cardona, "Techno-economic and energetic assessment of hydrogen production through gasification in the Colombian context: Coffee Cut-Stems case," Int. J. Hydrogen Energy, vol. 42, no. 9, pp. 58495864, 2017.

[45] L. E. Rincón, L. A. Becerra, J. Moncada, and C. A. Cardona, "Techno-economic analysis of the use of fired cogeneration systems based on sugar cane bagasse in south eastern and mid-western regions of Mexico," Waste and Biomass Valorization, vol. 5, no. 2, pp. 189-198, 2014.

[46] S. R. Rubio, F. E. Sierra, and A. Guerrero, "Gasificación de materiales orgáni- cos residuales Gasification from waste organic materials," Ing. e Investig., vol. 31, no. 3, pp. 17-25, 2011.

[47] R. A. Narvaez, G. Vargas, and F. Espinoza, "Potencial of waste-to-energy implementation in Ecuador," Int. J. Energy Eng., vol. 3, no. 6, pp. 279-286, 2013.

[48] N. L. Panwar, R. Kothari, and V. V Tyagi, "Thermo chemical conversion of biomass - Eco friendly energy routes," Renew. Sustain. Energy Rev., vol. 16, pp. 1801-1816, 2012.

[49] J. L. De Oliveira, J. N. Da Silva, E. Graciosa Pereira, D. Oliveira Filho, and D. Rizzo Carvalho, "Characterization and mapping of waste from coffee and eucalyptus production in Brazil for thermochemical conversion of energy via gasification," Renew. Sustain. Energy Rev., vol. 21, pp. 52-58, 2013.

[50] G. Bonassa et al., "Scenarios and prospects of solid biofuel use in Brazil," Renew. Sustain. Energy Rev., vol. 82, pp. 2365-2378, 2018.

[51] E. Virmond, R. F. De Sena, W. Albrecht, C. A. Althoff, R. F. P. M. Moreira, and H. J. José, "Characterisation of agroindustrial solid residues as biofuels and potential application in thermochemical processes," Waste Manag., vol. 32, no. 10, pp. 1952-1961, 2012.

[52] S. K. Sansaniwal, M. A. Rosen, and S. K. Tyagi, "Global challenges in the sustainable development of biomass gasification: An overview," Renewable and Sustainable Energy Reviews, vol. 80. pp. 23-43, 2017. 
[53] L. M. Romero Millán, F. E. Sierra Vargas, and A. Nzihou, "Kinetic Analysis of Tropical Lignocellulosic Agrowaste Pyrolysis," Bioenergy Res., vol. 10, no. 3, pp. 832-845, 2017.

[54] M. R. Delaney, R. Aggarwal, M. Henderson, and N. Chhetri, "An Analysis Of Biochar's Appropriateness And Strategic Action Plan For Its Adoption And Diffusion In A High Poverty Context: The Case Of Central Haiti," 2011.

[55] The Gleaner, "Used-tyre perspectives | Commentary | Jamaica Gleaner," 2011. [Online]. Available: http://jamaicagleaner.com/gleaner/20110324/cleisure/cleisure3.html. [Accessed: 28-Mar-2018].

[56] The Anguillian, "Letter To The Editor | The Anguillian Newspaper," Theanguillian.com, 2014. [Online]. Available: http://theanguillian.com/2014/03/letter-to-the-editor-74/. [Accessed: 12-May-2018].

[57] E. K. Brederode and K. de Cuba, "Justification and pre-feasibility study of an electrical interconnection for Saint Kitts and Nevis," 2009.

[58] U. R. Gracida-Alvarez, L. M. Keenan, J. C. Sacramento-Rivero, and D. R. Shonnard, "Resource and greenhouse gas assessments of the thermochemical conversion of municipal solid waste in Mexico," ACS Sustain. Chem. Eng., vol. 4, no. 11, pp. 59725978, 2016.

[59] G. C. Clarke, "Analysis of charcoal production systems in Guyana," 2010.

[60] S. De Gisi, L. Petta, and C. Wendland, "History and technology of Terra Preta sanitation," Sustain., vol. 6, no. 3, pp. 1328-1345, 2014.

[61] E. Virmond, J. D. Rocha, R. F. P. M. Moreira, and H. J. José, "Valorization of agroindustrial solid residues and residues from biofuel production chains by thermochemical conversion: a review, citing Brazil as a case study," Brazilian J. Chem. Eng., vol. 30, no. 2, pp. 197-230, Jun. 2013.

[62] A. de Oliveira Vilela, E. Silva Lora, Q. Roman Quintero, R. Ant, onio Vicintin, and T. Pacceli da Silva Souza, "A new technology for the combined production of charcoal and electricity through cogeneration," 2014.

[63] C. A. R. Bernardino, C. F. Mahler, M. C. C. Veloso, and G. A. Romeiro, "Preparation of Biochar from Sugarcane By-product Filter Mud by Slow Pyrolysis and Its Use Like 
Adsorbent," Waste and Biomass Valorization, vol. 8, no. 7, pp. 2511-2521, 2017.

[64] A. T. Filho, "Aplicação do processo de pirólise para valoração, cogeração de energia e tratamento de resíduos," p. 173, 2014.

[65] M. E. Doumer et al., "Slow pyrolysis of different Brazilian waste biomasses as sources of soil conditioners and energy, and for environmental protection," J. Anal. Appl. Pyrolysis, vol. 113, pp. 434-443, 2015.

[66] A. F. González-Rojas and L. M. Aranzazu-Ríos, "Análisis Termogravimétrico y Estudio Cinético de la Pirólisis de Residuos Sólidos Veterinarios Thermogravimetric Analysis and Kinetic Study on Pyrolysis of Veterinarian Solid Waste," Rev. Ing., pp. 276-289, 2016.

[67] N. Abdullah, F. Sulaiman, M. Azman Miskam, and T. Rahmad Mohd, "Characterization of Banana (Musaspp.) Pseudo-Stem and Fruit-Bunch-Stem as a Potential Renewable EnergyResource," 2016.

[68] T. Lönnqvist et al., "Large-scale biogas generation in Bolivia - A stepwise reconfiguration," J. Clean. Prod., vol. 180, pp. 494-504, 2018.

[69] L. T. Fuess, M. M. de Araújo Júnior, M. L. Garcia, and M. Zaiat, "Designing full-scale biodigestion plants for the treatment of vinasse in sugarcane biorefineries: How phase separation and alkalinization impact biogas and electricity production costs?," Chem. Eng. Res. Des., vol. 119, pp. 209-220, 2017.

[70] M. Garfí, L. Ferrer-Martí, I. Perez, X. Flotats, and I. Ferrer, "Codigestion of cow and guinea pig manure in low-cost tubular digesters at high altitude," Ecol. Eng., vol. 37, no. 12, pp. 2066-2070, 2011.

[71] S. Lansing, A. Maile-Moskowitz, and A. Eaton, "Waste treatment and energy production from small-scale wastewater digesters," Bioresour. Technol., vol. 245, pp. 801-809, Dec. 2017.

[72] Ideass, "Low cost biodigesters - To produce biogas and natural fertilizer from organic waste idea," 2008.

[73] V. Martijn, J. Borobio, F. Acosta, and G. Ameller, "Estudio de Factibilidad para un Programa Nacional de Biogas Doméstico en Bolivia," 2012. 
[74] I. Ferrer, M. Gamiz, M. Almeida, and A. Ruiz, "Pilot project of biogas production from pig manure and urine mixture at ambient temperature in Ventanilla (Lima, Peru)," Waste Manag., vol. 29, no. 1, pp. 168-173, 2009.

[75] INDAP and GORE, "Biogás de residuos agropecuarios en la región de los ríos," 2016.

[76] L. C. Mattos and M. F. Junior, Manual do Biodigestor Sertanejo. 2011.

[77] Mercosur Ad Hoc Group on Biofuels - GAHB, "Biogas and biomethane report in Mercosur," 2017.

[78] CIBIOGAS, "mapbiogas.cibiogas.org," Map Biogas Brazil, 2019. [Online]. Available: http://mapbiogas.cibiogas.org/. [Accessed: 14-Jun-2019].

[79] R. Bonnell, V. S. Raghavan, and A. Consigny, "Wastewater Biogas Digester System for a Rural Residence in Barbados Design Project Presented to Project performed by Barbados Field Study Semester," 2005.

[80] IICA, "Installation of a Low Cost Polyethylene Biodigester," 2009.

[81] MSPP (Ministere Sante Publique et de la Population Haiti), "Rapport du Réseau National de Surveillance MINISTERE SANTE PUBLIQUE ET DE LA POPULATION (MSPP) Direction d'Epidémiologie de Laboratoire et de Recherches (DELR)," 2017.

[82] College of Agriculture and Natural Resources, "Haiti Biogas Project | Environmental Science \&amp; Technology," $2015 . \quad$ [Online]. Available: https://enst.umd.edu//people/faculty/stephanie-lansing/haiti-biogas-project. [Accessed: 04-Feb-2018].

[83] O. Ortíz-Satiago, L. R. Pérez-Alegría, and F. Pantoja-Agreda, "Anaerobic digestion of dairy manure for energy and nutrients recovery," Int. Symp. is not a peer-reviewed Artic., no. 701, pp. 368-375, 2003.

[84] S. Lansing, R. B. Botero, and J. F. Martin, "Waste treatment and biogas quality in smallscale agricultural digesters," Bioresour. Technol., vol. 99, no. 13, pp. 5881-5890, 2008.

[85] S. Lansing, J. Víquez, H. Martínez, R. Botero, and J. Martin, "Quantifying electricity generation and waste transformations in a low-cost, plug-flow anaerobic digestion system," Ecol. Eng., vol. 34, no. 4, pp. 332-348, 2008. 
[86] M. N. Kinyua, J. Zhang, F. Camacho-Céspedes, A. Tejada-Martinez, and S. J. Ergas, "Use of physical and biological process models to understand the performance of tubular anaerobic digesters," Biochem. Eng. J., vol. 107, pp. 35-44, 2016.

[87] S. Lansing, J. F. Martin, R. B. Botero, T. N. da Silva, and E. D. da Silva, "Methane production in low-cost, unheated, plug-flow digesters treating swine manure and used cooking grease," Bioresour. Technol., vol. 101, no. 12, pp. 4362-4370, 2010.

[88] S. Lansing, J. F. Martin, R. B. Botero, T. Nogueira da Silva, and E. Dias da Silva, "Wastewater transformations and fertilizer value when co-digesting differing ratios of swine manure and used cooking grease in low-cost digesters," Biomass and Bioenergy, vol. 34, no. 12, pp. 1711-1720, 2010.

[89] I. Ferrer, M. Garfí, E. Uggetti, L. Ferrer-Martí, A. Calderon, and E. Velo, "Biogas production in low-cost household digesters at the Peruvian Andes," Biomass and Bioenergy, vol. 35, no. 5, pp. 1668-1674, 2011.

[90] J. Martí, Desarrollo, difusión e implementación de tecnologías en el área rural: Biodigestores en Bolivia, vol. 1. 2015.

[91] J. Ferrell and K. Cockerill, "Closing coffee production loops with waste to ethanol in Matagalpa, Nicaragua," Energy Sustain. Dev., vol. 16, no. 1, pp. 44-50, 2012.

[92] E. Voegele, "Organic Power to install 2 MW AD plant in Puerto Rico," Biomass Magazine, 2018. [Online]. Available: http://biomassmagazine.com/articles/15045/organic-power-to-install-2-mw-ad-plantin-puerto-rico.

[93] INTA (Instituto Nacional de Tecnología Agropecuaria), "Relevamiento nacional de plantas de biogás I Instituto Nacional de Tecnología Agropecuaria," 2016. [Online]. Available: https://inta.gob.ar/documentos/relevamiento-nacional-de-plantas-debiogas. [Accessed: 05-Apr-2018].

[94] B. Morero, R. Vicentin, and E. A. Campanella, "Assessment of biogas production in Argentina from co-digestion of sludge and municipal solid waste," Waste Manag., vol. 61, pp. 195-205, 2017.

[95] R. Chamy and E. Vivanco, "Identification and classification of different types of biomass 
available in Chile for the generation of biogas. Energías Renovables No Convencionales en Chile (CNE/GTZ);," 2007.

[96] F. R. P. Arrieta, F. N. Teixeira, E. Yáñez, E. Lora, and E. Castillo, "Cogeneration potential in the Columbian palm oil industry: Three case studies," Biomass and Bioenergy, vol. 31, no. 7, pp. 503-511, Jul. 2007.

[97] CEC, "Characterization and Management of Organic Waste in North AmericaFoundational Report," Montreal, Canada, 2017.

[98] M. Rios and M. Kaltschmitt, "Electricity generation potential from biogas produced from organic waste in Mexico," Renew. Sustain. Energy Rev., vol. 54, pp. 384-395, 2016.

[99] Agencia EFE, "Inauguran en Ciudad de México biodigestor para tratamiento de residuos," $\quad$ www.efe.com, $2017 . \quad$ [Online]. Available: https://www.efe.com/efe/america/mexico/inauguran-en-ciudad-de-mexicobiodigestor-para-tratamiento-residuos/50000545-3276567. [Accessed: 16-Oct-2018].

[100] Bekon, "Bekon references and current contacts," www.bekon.eu/en/, 2018. [Online]. Available: https://www.bekon.eu/en/references/. [Accessed: 12-Nov-2018].

[101] SUEMA, "Cactus Power | 24 Hours of Reality | Mexico City," 2018. [Online]. Available: https://www.youtube.com/watch?v=RdlynzAVjGE\&t=21s. [Accessed: 28-May-2019].

[102] R. Castro-Muñoz, V. Fíla, and E. Durán-Páramo, "A Review of the Primary By-product (Nejayote) of the Nixtamalization During Maize Processing: Potential Reuses," Waste and Biomass Valorization, vol. 0, no. 0, pp. 1-10, 2017.

[103] M. E. González-Sánchez, S. Pérez-Fabiel, A. Wong-Villarreal, R. Bello-Mendoza, and G. Yãnez-Ocampo, "Residuos agroindustriales con potencial para la producción de metano mediante la digestión anaerobia," Rev. Argent. Microbiol., vol. 47, no. 3, pp. 229-235, 2015.

[104] H. O. Méndez-Acosta, R. Snell-Castro, V. Alcaraz-González, V. González-Álvarez, and C. Pelayo-Ortiz, "Anaerobic treatment of Tequila vinasses in a CSTR-type digester," Biodegradation, vol. 21, no. 3, pp. 357-363, 2010.

[105] I. L. Moreda, "The potential of biogas production in Uruguay," Renew. Sustain. Energy 
Rev., vol. 54, pp. 1580-1591, 2016.

[106] M. J. M. Davis, D. J. Polit, and M. Lamour, "Social Urban Metabolism Strategies (SUMS) for Cities," Procedia Environ. Sci., vol. 34, pp. 309-327, 2016.

[107] M. Garfí, P. Gelman, J. Comas, W. Carrasco, and I. Ferrer, "Agricultural reuse of the digestate from low-cost tubular digesters in rural Andean communities," Waste Manag., vol. 31, no. 12, pp. 2584-2589, 2011.

[108] J. Montenegro, "Brazil could generate 115,000GWh/year from biogas," 2018. [Online]. Available: $\quad$ https://www.bnamericas.com/en/news/electricpower/brazil-couldgenerate-115000-gwh-year-from-biogas/. [Accessed: 08-Mar-2018].

[109] B. V. R. Pin, R. M. Barros, E. E. Silva Lora, and I. F. S. dos Santos, "Waste management studies in a Brazilian microregion: GHG emissions balance and LFG energy project economic feasibility analysis," Energy Strateg. Rev., vol. 19, pp. 31-43, 2018.

[110] I. F. Silva dos Santos, N. D. Braz Vieira, L. G. B. de Nóbrega, R. M. Barros, and G. L. Tiago Filho, "Assessment of potential biogas production from multiple organic wastes in Brazil: Impact on energy generation, use, and emissions abatement," Resour. Conserv. Recycl., vol. 131, pp. 54-63, 2018.

[111] O. Konrad, F. F. Koch, M. Lumi, J. F. Tonetto, and A. Bezama, "Potential of Biogas Production From Swine Manure Supplemented," Eng. Agrícola, vol. 34, no. 5, pp. 844853, 2014.

[112] L. M. Goulart Coelho and L. C. Lange, "Applying life cycle assessment to support environmentally sustainable waste management strategies in Brazil," Resour. Conserv. Recycl., vol. 128, pp. 438-450, 2018.

[113] C. Mersoni and G. A. Reichert, "Comparação de cenários de tratamento de resíduos sólidos urbanos por meio da técnica da Avaliação do Ciclo de Vida: o caso do município de Garibaldi, RS," Eng. Sanit. e Ambient., vol. 22, no. 5, pp. 863-875, 2017.

[114] L. Janke et al., "Biogas Production from Sugarcane Waste: Assessment on Kinetic Challenges for Process Designing," Int. J. Mol. Sci., vol. 16, no. 9, pp. 20685-20703, 2015.

[115] R. Ferreira-Santos, A. Borsoi, D. Secco, S. N. Melegari de Souza, and R. N. Constanzi, 
"Brazil's Potential for Generating Electricity from Biogas from Stillage," World Renew. Energy Congr. 2011, pp. 425-432, 2011.

[116] USP, "Resíduo da produção de etanol é matéria-prima para biogás," Jornal da USP, 2017. [Online]. Available: http://jornal.usp.br/ciencias/ciencias-ambientais/residuo-daproducao-de-etanol-e-materia-prima-para-biogas/. [Accessed: 17-Jun-2018].

[117] B. S. Moraes et al., "Anaerobic digestion of vinasse from sugarcane biorefineries in Brazil from energy, environmental, and economic perspectives: Profit or expense?," Appl. Energy, vol. 113, pp. 825-835, 2014.

[118] B. S. Moraes, M. Zaiat, and A. Bonomi, "Anaerobic digestion of vinasse from sugarcane ethanol production in Brazil: Challenges and perspectives," Renew. Sustain. Energy Rev., vol. 44, pp. 888-903, 2015.

[119] E. F. Granato, “Análise de viabilidade técnica e econômica da biodigestão Anaeróbia da vinhaça," Universidade Estadual Paulista, 2016.

[120] A. P. Bernal, I. F. S. dos Santos, A. P. Moni Silva, R. M. Barros, and E. M. Ribeiro, "Vinasse biogas for energy generation in Brazil: An assessment of economic feasibility, energy potential and avoided CO2 emissions," J. Clean. Prod., vol. 151, pp. 260-271, 2017.

[121] B. F. Naspolini, A. C. de O. Machado, W. B. Cravo Junior, D. M. G. Freire, and M. C. Cammarota, "Bioconversion of Sugarcane Vinasse into High-Added Value Products and Energy," Biomed Res. Int., vol. 2017, pp. 1-11, 2017.

[122] R. Albanez et al., "Anaerobic Biological Treatment of Vinasse for Environmental Compliance and Methane Production," Appl. Biochem. Biotechnol., vol. 178, no. 1, pp. 21-43, 2016.

[123] L. T. Fuess and M. L. Garcia, "Bioenergy from stillage anaerobic digestion to enhance the energy balance ratio of ethanol production," J. Environ. Manage., vol. 162, pp. 102-114, 2015.

[124] Investe São Paulo, "Raízen and Geo Energética announce the construction of a biogas plant supported by Investe São Paulo," 2018. [Online]. Available: https://www.en.investe.sp.gov.br/news/post/raizen-and-geo-energetica-announce- 
the-construction-of-a-biogas-plant-supported-by-investe-sao-paulo/. [Accessed: 28May-2019].

[125] Folha de S. Paulo, "Usina Cocal fará fornecimento de gás de bagaço de cana-de-açúcar a cidades de São Paulo." www.novacana.com, 2019.

[126] M. Ohde, "Paraná terá a primeira usina do Brasil de produção de energia a partir do lodo de esgoto," Paraná Portal, p. 1, 2018.

[127] L. F. de D. B. Colturato, T. D. B. Colturato, F. C. de S. P. Gomes, and T. A. Seraval, O estado da arte da tecnologia de metanização seca, vol. 1. 2015.

[128] Chernicharo C. A. L., B. O. Ferreira, L. C. S. Lobato, L. F. D. Colturato, L. E. G. Pereira, and f. J. P. Pujatti, "Strategies for Energy Recovery and Gains Associated with the Implementation of an Extra-Dry Methanization System for Treating Organic Waste from the City of Rio De Janeirorogramme.eubce.com," in EUBCE 2018 Conference Proceedings, 2018.

[129] R. Alvarez and G. Lidén, "Anaerobic co-digestion of aquatic flora and quinoa with manures from Bolivian Altiplano," Waste Manag., vol. 28, no. 10, pp. 1933-1940, 2008.

[130] C. Santibáñez, M. T. Varnero, and M. Bustamante, "Residual Glycerol from Biodiesel Manufacturing, Waste or Potential Source of Bioenergy: A Review," Chil. J. Agric. Res., vol. 71, no. 3, pp. 469-475, 2011.

[131] P. Bres et al., "Performance of semi-continuous anaerobic co-digestion of poultry manure with fruit and vegetable waste and analysis of digestate quality: A bench scale study," Waste Manag., vol. 82, no. November, pp. 276-284, 2018.

[132] A. Rodríguez et al., "Evaluation of the biochemical methane potential of pig manure, organic fraction of municipal solid waste and cocoa industry residues in Colombia," Chem. Eng. Trans., vol. 57, pp. 55-60, 2017.

[133] I. Cabeza, M. Thomas, A. Vázquez, P. Acevedo, and M. Hernández, "Anaerobic Codigestion of Organic Residues from Different Productive Sectors in Colombia: Biomethanation Potential Assessment," 5th Int. Symp. Ind. Biotechnol. (Ibic 2016), vol. 49, pp. 385-390, 2016. 
[134] SNV, PNUD, and SERNA, "Estudio sobre el potencial de desarrollo de iniciativas de biogás a nivel productivo en Honduras," 2012.

[135] L. M. Cárdenas Cleves, B. A. Parra Orobio, P. Torres Lozada, and C. H. Vásquez Franco, “Perspectivas del ensayo de Potencial Bioquímico de Metano - PBM para el control del proceso de digestión anaerobia de residuos," Rev. Investig. Optim. y Nuevos procesos en Ing., vol. 29, no. 1, pp. 95-108, 2016.

[136] A. Meneses-Jácome, R. Diaz-Chavez, H. I. Velásquez-Arredondo, D. L. Cárdenas-Chávez, R. Parra, and A. A. Ruiz-Colorado, "Sustainable Energy from agro-industrial wastewaters in Latin-America," Renew. Sustain. Energy Rev., vol. 56, pp. 1249-1262, 2016.

[137] R. Janssen and D. D. Rutz, "Sustainability of biofuels in Latin America: Risks and opportunities," Energy Policy, vol. 39, no. 10, pp. 5717-5725, 2011.

[138] D. Rutz et al., "Biofuels Assessment on Technical Opportunities and Research Needs for Latin America Final Report," Biofuels Top; Biofuels RTD-Cooperation Lat. Am., 2010.

[139] FAS Quito, "Ecuador Ethanol Industry Emerging in Ecuador," 2018.

[140] J. C. Garcia M, T. MacHimura, and T. Matsui, "Optimizing plant allocation for bioethanol production from agro-residues considering CO2emission and energy demand-supply balance: A case study in ecuador," Waste and Biomass Valorization, vol. 3, no. 4, pp. 435-442, 2012.

[141] J. Moncada, J. Tamayo, and C. A. Cardona, "Evolution from biofuels to integrated biorefineries: Techno-economic and environmental assessment of oil palm in Colombia," J. Clean. Prod., vol. 81, pp. 51-59, 2014.

[142] A. Iriarte, J. Rieradevall, and X. Gabarrell, "Transition towards a more environmentally sustainable biodiesel in South America: The case of Chile," Appl. Energy, vol. 91, no. 1, pp. 263-273, 2012.

[143] A. Limayem and S. C. Ricke, "Lignocellulosic biomass for bioethanol production: Current perspectives, potential issues and future prospects," Prog. Energy Combust. Sci., vol. 38, pp. 449-467, 2012.

[144] S. Scott, "Jamaica Observer Limited," 2013. [Online]. Available: 
http://www.jamaicaobserver.com/business/Petrojam-Ethanol-ends-4-yeardrought_14032271. [Accessed: 05-Feb-2018].

[145] K. De Cuba, F. Burgos, R. Contreras-Lisperguer, and R. Penny, "Limits and potential of Waste to Energy systems in the Caribbean," Dep. Sustain. Dev. Organ. Am. States, no. May, 2017.

[146] www.wholelattelove.com, "Coffee Growing in Latin America," www.wholelattelove.com, $2018 . \quad$ [Online]. Available: https://www.wholelattelove.com/blog/coffee-growing-regions-latin-america. [Accessed: 03-Aug-2018].

[147] M. K. D. Rambo, F. L. Schmidt, and M. M. C. Ferreira, "Analysis of the lignocellulosic components of biomass residues for biorefinery opportunities," Talanta, vol. 144, pp. 696-703, 2015.

[148] OXFAM, "The next frontier for palm oil expansion: Latin America," 2016. [Online]. Available: https://politicsofpoverty.oxfamamerica.org/2016/10/the-next-frontier-forpalm-oil-expansion-latin-america/. [Accessed: 04-Jun-2018].

[149] H. I. Velásquez-Arredondo, A. A. Ruiz-Colorado, and S. De Oliveira, "Ethanol production process from banana fruit and its lignocellulosic residues: Energy analysis," Energy, vol. 35, no. 7, pp. 3081-3087, 2010.

[150] J. C. G. M., T. Machimura, T. Matsui, J. C. Garcia M., T. Machimura, and T. Matsui, “A Nation-wide Planning of Agro-residue Utility for Bioethanol Production and Power Generation in Ecuador," Energy Procedia, vol. 34, pp. 57-63, 2013.

[151] A. B. Guerrero, P. L. Aguado, J. Sánchez, and M. D. Curt, "GIS-Based Assessment of Banana Residual Biomass Potential for Ethanol Production and Power Generation: A Case Study," Waste and Biomass Valorization, vol. 7, no. 2, pp. 405-415, 2016.

[152] A. B. Guerrero and E. Muñoz, "Life cycle assessment of second generation ethanol derived from banana agricultural waste: Environmental impacts and energy balance," J. Clean. Prod., vol. 174, pp. 710-717, 2018.

[153] M. O. S. Dias et al., "Second generation ethanol in Brazil: Can it compete with electricity production?," Bioresour. Technol., vol. 102, no. 19, pp. 8964-8971, 2011. 
[154] D. Khatiwada, S. Leduc, S. Silveira, and I. McCallum, "Optimizing ethanol and bioelectricity production in sugarcane biorefineries in Brazil," Renew. Energy, vol. 85, pp. 371-386, 2016.

[155] V. E. N. Santos, R. N. Ely, A. S. Szklo, and A. Magrini, "Chemicals, electricity and fuels from biorefineries processing Brazil's sugarcane bagasse: Production recipes and minimum selling prices," 2015.

[156] T. L. Junqueira et al., "Techno-economic analysis and climate change impacts of sugarcane biorefineries considering different time horizons," Biotechnol. Biofuels, vol. 10, no. 1, p. 50, 2017.

[157] L. Wang, R. Quiceno, C. Price, R. Malpas, and J. Woods, "Economic and GHG emissions analyses for sugarcane ethanol in Brazil: Looking forward," Renew. Sustain. Energy Rev., vol. 40, pp. 571-582, 2014.

[158] F. A. Gonçalves, E. S. Dos Santos, and G. R. De Macedo, "Use of cultivars of low cost, agroindustrial and urban waste in the production of cellulosic ethanol in Brazil: A proposal to utilization of microdistillery," Renew. Sustain. Energy Rev., vol. 50, pp. 1287-1303, 2015.

[159] L. Caspeta, M. A. Caro-Bermúdez, T. Ponce-Noyola, and A. Martinez, "Enzymatic hydrolysis at high-solids loadings for the conversion of agave bagasse to fuel ethanol," Appl. Energy, vol. 113, pp. 277-286, 2014.

[160] J. R. Mielenz, M. Rodriguez, O. A. Thompson, X. Yang, and H. Yin, "Development of Agave as a dedicated biomass source: Production of biofuels from whole plants," Biotechnol. Biofuels, vol. 8, no. 1, pp. 1-13, 2015.

[161] I. Barrera, M. A. Amezcua-Allieri, L. Estupiñan, T. Martínez, and J. Aburto, "Technical and economical evaluation of bioethanol production from lignocellulosic residues in Mexico: Case of sugarcane and blue agave bagasses," Chem. Eng. Res. Des., vol. 107, pp. 91-101, 2016.

[162] E. S. Jensen et al., Legumes for mitigation of climate change and the provision of feedstock for biofuels and biorefineries. A review, vol. 32, no. 2. 2012.

[163] M. A. Lima et al., "Evaluating the composition and processing potential of novel 
sources of Brazilian biomass for sustainable biorenewables production," Biotechnol. Biofuels, vol. 7, no. 1, pp. 1-19, 2014.

[164] E. Bastías, M. Díaz M., P. Pacheco C., R. Bustos P, and E. Hurtado C, "Caracterización del maíz 'Lluteño' (Zea mays L. tipo amylacea) proveniente del norte de Chile, tolerante a $\mathrm{NaCl}$ y exceso de boro, como una alternativa para la producción de bioenergía," Idesia (Arica), vol. 29, no. 3, pp. 7-16, 2011.

[165] S. I. Mussatto, J. Moncada, I. C. Roberto, and C. A. Cardona, "Techno-economic analysis for brewer's spent grains use on a biorefinery concept: The Brazilian case," Bioresour. Technol., vol. 148, pp. 302-310, 2013.

[166] M. P. Zacharof, "Grape Winery Waste as Feedstock for Bioconversions: Applying the Biorefinery Concept," Waste and Biomass Valorization, vol. 8, no. 4, pp. 1011-1025, 2017.

[167] P. Schroeder, M. Dos Santos Barreto, G. A. Romeiro, and M. K. K. Figueiredo, "Development of Energetic Alternatives to Use of Waste of Annona muricata L.," Waste and Biomass Valorization, vol. 0, no. 0, pp. 1-9, 2017.

[168] P. D. Pathak, S. A. Mandavgane, and B. D. Kulkarni, "Waste to Wealth: A Case Study of Papaya Peel," Waste and Biomass Valorization, vol. 0, no. 0, p. 0, 2018.

[169] J. A. Quintero, J. Moncada, and C. A. Cardona, "Techno-economic analysis of bioethanol production from lignocellulosic residues in Colombia: A process simulation approach," Bioresour. Technol., vol. 139, pp. 300-307, 2013.

[170] P. N. Robledo-Narváez et al., "The influence of total solids content and initial pH on batch biohydrogen production by solid substrate fermentation of agroindustrial wastes," J. Environ. Manage., vol. 128, pp. 126-137, 2013.

[171] F. Posso, R. A. Narváez C., J. Siguencia, and J. Sánchez, "Use of Municipal Solid Waste (MSW)-Derived Hydrogen in Ecuador: Potential Applications for Urban Transportation," Waste and Biomass Valorization, vol. 0, no. 0, pp. 1-9, 2017.

[172] C. J. A. Mota and R. S. Monteiro, "Química e sustentabilidade: novas fronteiras em biocombustíveis," Quim. Nova, vol. 36, no. 10, pp. 1483-1490, 2013.

[173] UNSD, "Turning waste into resources: Latin America's waste-to-energy landfills," 2011. 
[174] S. Renou, J. G. Givaudan, S. Poulain, F. Dirassouyan, and P. Moulin, "Landfill leachate treatment: Review and opportunity," J. Hazard. Mater., vol. 150, pp. 468-493, 2008.

[175] UNEP, "Management of Wastes in Small Islands Developing States. Progress in the implementation of the Programme of Action for the Sustainable Development of Small Island Developing States," 1998. [Online]. Available: http://islands.unep.ch/dd987a2.htm. [Accessed: 03-Apr-2018].

[176] UNFCCC, "CDM: Public," $2017 . \quad$ [Online]. Available: http://cdm.unfccc.int/Statistics/Public/index.html. [Accessed: 09-Apr-2018].

[177] P. Kowlesser, "Solid Waste Management in Mauritius Solid Waste Management Division Ministry of Local Government and Outer Islands, Mauritius," 2012.

[178] GoldfieldSolar, "Waste to Energy Plant in the US Virgin Islands," 2016. [Online]. Available: https://medium.com/goldfield-solar-news/waste-to-energy-plant-in-the-usvirgin-islands-8e8b5b1a57fb. [Accessed: 18-Apr-2018].

[179] C. Wilson, "Baseline Study of Energy Policies \& Legislation in Selected Caribbean Countries, July 2009 | Renewable Energy | World Energy Consumption," 2009. [Online]. Available: https://pt.scribd.com/document/92001942/Baseline-Study-ofEnergy-Policies-Legislation-in-Selected-Caribbean-Countries-July-2009. [Accessed: 04Apr-2018].

[180] Government of St. Vincent and the Grenadines, "Energy Action Plan for St. Vincent and the Grenadines," 2010.

[181] Organization of American States, "Energy Policy and Sector Analysis in the Caribbean," 2010.

[182] A. Bezama et al., "Life cycle comparison of waste-to-energy alternatives for municipal waste treatment in Chilean Patagonia," Waste Manag. Res., vol. 31, no. 10 SUPPL., pp. 67-74, 2013.

[183] W. C. Nadaletti et al., Potential use of landfill biogas in urban bus fleet in the Brazilian states: A review, vol. 41, no. 2. 2015, pp. 277-283.

[184] F. A. M. Lino and K. A. R. Ismail, "Energy and environmental potential of solid waste in Brazil," Energy Policy, vol. 39, no. 6, pp. 3496-3502, 2011. 
[185] Ministério-de-Minas-e-Energia, "RenovaBio permite aproveitamento energético de aterros sanitários," Minas e Energia, p. 1, 2018.

[186] J. M. Ferreira-Coelho, "Artigo perspectivas para o setor de biocombustiveis do Brasil em 2018," 2018.

[187] E. do Ceará, "Cegás apresenta na Expobiogás experiência pioneira de distribuição de biometano no $\quad$ Brasil," $2019 . \quad$ [Online]. Available: https://www.ceara.gov.br/2019/05/24/cegas-apresenta-na-expobiogas-experienciapioneira-de-distribuicao-de-biometano-no-brasil/. [Accessed: 04-Jun-2019].

[188] C. Escamilla-Alvarado, H. M. Poggi-Varaldo, and M. T. Ponce-Noyola, "Bioenergy and bioproducts from municipal organic waste as alternative to landfilling: a comparative life cycle assessment with prospective application to Mexico," Environ. Sci. Pollut. Res., vol. 24, no. 33, pp. 25602-25617, 2017.

[189] ISWA, "Closure of San Vicente Dumpsite, Buenos Aires, Argentina," 2017. [Online]. Available: http://www.iswa.org/home/news/news-detail/browse/1/article/closure-ofsan-vicente-dumpsite-buenos-aires-argentina/109/legal-notices/. [Accessed: 12-Aug2018].

[190] ISWA, "Closing one of Latin America's Biggest Dumpsites," 2017. [Online]. Available: https://www.iswa.org/home/news/news-detail/browse/12/article/closing-one-oflatin-americas-biggest-dumpsites/109/terms-and-conditions/. [Accessed: 07-Mar2018].

[191] BBC, "Mexico City closes Bordo Poniente rubbish dump," 2011. [Online]. Available: http://www.bbc.com/news/world-latin-america-16258472. [Accessed: 19-Apr-2018].

[192] K. Tota-Maharaj and P. Paul, "Performance of pilot-scale microbial fuel cells treating wastewater with associated bioenergy production in the Caribbean context," Int. J. Energy Environ. Eng., vol. 6, no. 3, pp. 213-220, 2015.

[193] G. Hernández-Flores, O. Solorza-Feria, and H. M. Poggi-Varaldo, "Bioelectricity generation from wastewater and actual landfill leachates: A multivariate analysis using principal component analysis," Int. J. Hydrogen Energy, vol. 42, no. 32, pp. 2077220782, 2017. 
[194] S. Rachinski, A. Carubelli, A. P. Mangoni, and A. S. Mangrich, "Pilhas de combustíveis microbianas utilizadas na produção de eletricidade a partir de rejeitos orgánicos: Uma perspectiva de futuro," Quim. Nova, vol. 33, no. 8, pp. 1773-1778, 2010.

[195] K. R. of the electric energy generating potential for different sources of biogas in B. Salomon and E. E. Silva Lora, "Estimate of the electric energy generating potential for different sources of biogas in Brazil," Biomass and Bioenergy, vol. 33, no. 9, pp. 11011107, 2009.

[196] C2ES, "Submitted Intended Nationally Determined Contributions (INDCs) Center for Climate and Energy Solutions," 2016. [Online]. Available: https://www.c2es.org/international/2015-agreement/indcs. [Accessed: 25-Feb-2018]. 